
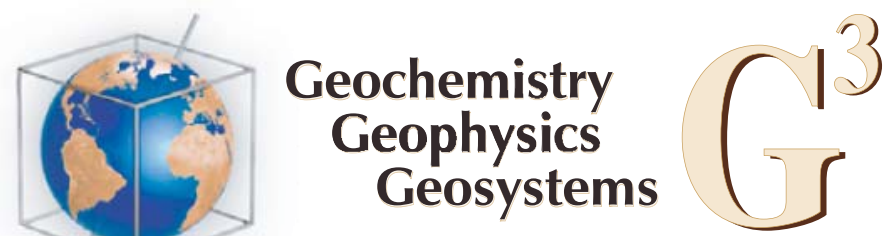

\title{
Grain size control of river suspended sediment geochemistry: Clues from Amazon River depth profiles
}

\author{
Julien Bouchez and Jérôme Gaillardet
}

Institut de Physique du Globe de Paris-Sorbonne Paris Cité, Université Paris Diderot, UMR 7154, 1 rue Jussieu, F-75238 Paris CEDEX 05, France (bouchez@ipgp.jussieu.fr)

\section{Christian France-Lanord}

Centre de Recherches Pétrographiques et Geochimiques-Centre National pour la Recherche Scientifique, 15 rue Notre-Dame-des-Pauvres, F-54501 Vandoeuvre-lès Nancy, France

\section{Laurence Maurice and Poliana Dutra-Maia}

Laboratoire des Mécanismes de Transfert en Géologie-Institut de Recherche pour le Developpement, 14 Avenue Edouard Belin, F-31400 Toulouse, France

[1] Residual solid products of erosion display a wide range of size, density, shape, mineralogy, and chemical composition and are hydrodynamically sorted in large river channels during their transport. We characterize the chemical and isotopic variability of river sediments of the Amazon Basin, collected at different water depths, as a function of grain size. Absolute chemical concentrations and $\mathrm{Sr}$ and $\mathrm{Nd}$ isotopic ratios greatly varies along channel depth. The $\mathrm{Al} / \mathrm{Si}$ ratio, tightly linked to grain size distribution, systematically decreases with depth, mostly reflecting dilution by quartz minerals. A double-normalization diagram is proposed to correct from dilution effects. Elements define fan-shaped patterns and can be classified in three different groups with respect to hydrodynamic sorting during transport in the Amazon: (1) "poorly sorted" insoluble elements like Al, Fe, Th, and REEs, (2) "well-sorted" insoluble elements like $\mathrm{Zr}$ and Ti, mainly carried by heavy minerals, and (3) alkali ( $\mathrm{Na}$ to $\mathrm{Cs}$ ) and alkali-earth elements ( $\mathrm{Mg}$ to $\mathrm{Ba}$ ), for which a large variety of patterns is observed, related, for alkali, to their variable affinity for phyllosilicates. Sr isotopes show that the Amazon River at the mouth is stratified, the Madeira- and Solimões-derived sediments being preferentially transported near the channel surface and at depth, respectively. The comparison between the Solimões and Madeira rivers shows how the interplay between grain sorting, weathering, and crustal composition controls the composition of the suspended river sediments.

Components: 23,300 words, 9 figures, 3 tables.

Keywords: Amazon River; suspended sediments; hydrodynamic sorting; depth profiles; grain size.

Index Terms: 1030 Geochemistry: Geochemical cycles (0330); 1051 Geochemistry: Sedimentary geochemistry; 1862 Hydrology: Sediment transport (4558).

Received 6 October 2010; Revised 5 January 2011; Accepted 13 January 2011; Published 26 March 2011.

Bouchez, J., J. Gaillardet, C. France-Lanord, L. Maurice, and P. Dutra-Maia (2011), Grain size control of river suspended sediment geochemistry: Clues from Amazon River depth profiles, Geochem. Geophys. Geosyst., 12, Q03008, doi:10.1029/2010GC003380. 


\section{Introduction}

[2] Erosion and weathering reactions are key geological processes, through which the chemical elements present in the continental rocks are distributed amongst river solutes, colloidal material, suspended sediments, bed sediments, gravels and boulders. Despite the relatively small number of studies that investigated the chemical composition of large river suspended sediments [Martin and Meybeck, 1979; Gaillardet et al., 1999; Viers et al., 2009, and references therein], the available data show a great variability with climatic, geomorphic and tectonic settings, suggesting that the solid material transported by rivers contains important information on chemical weathering. So far, river suspended sediments have been used (1) to characterize the weathering intensity at the scale of the drainage basin using the most soluble elements (mainly alkali and alkali-earth elements) [e.g., Canfield, 1997; Gaillardet et al., 1999], (2) to integrate the chemical and isotopic composition of the drained portion of upper continental crust and constrain its history, using the most insoluble elements (i.e., not partitioned between dissolved and particulate phase and concentrated in the latter) [Dupré et al., 1996; Louvat and Allègre, 1997], or $\mathrm{Nd}$ and $\mathrm{Pb}$ isotopes [Goldstein and Jacobsen, 1988; Allègre et al., 1996; Millot et al., 2004], (3) to detect anthropogenic contamination for metals [Meybeck and Ragu, 1996; Chen et al., 2009], (4) to estimate the flux of particulate organic carbon that is delivered to the sea [France-Lanord and Derry, 1997; Galy et al., 2007; Hilton et al., 2008], and (5) to estimate the residence time of particles in drainage basins, based on U series disequilibria [Vigier et al., 2001; Dosseto et al., 2006; Granet et al., 2007].

[3] Most of these studies rely on suspended sediment samples taken at the surface of the river channel, at one single sampling time. However, river suspended sediment concentration and grain size distribution vary as a function of sampling depth, because of hydrodynamic sorting of particles [Bouchez et al., 2010a], which likely results in a chemical variability of the suspended load over depth [Galy et al., 2008; Garzanti et al., 2010a]. Time series of river suspended sediment chemistry clearly demonstrate that the chemical and isotopic composition of sediments varies throughout the hydrological cycle [e.g., Viers et al., 2008]. Changing river flow conditions throughout the hydrological cycle influences the particles sorting process, which can explain some of the temporal variability of chemistry observed in river surface suspended sediments.

[4] In this paper, we investigate the chemical and isotopic effects of hydrodynamic sorting within the river water column in the Amazon River and its two main Andean tributaries, the Solimões and Madeira rivers. The aim of our approach is to establish distributions of elements as a function of grain size in the largest river system of the world in order to capture the geochemical behavior of elements with respect to sorting processes at a large scale. Although mineralogical composition links grain size distribution of sediments to their chemical composition [Garzanti et al., 2010a], this contribution is not a mineralogical study but rather addresses the global behavior of elements regarding a geological process from a geochemical perspective (e.g., similarly to what was done for partial melting) [Hofmann, 1988].

[5] The Amazon is the appropriate river system to test the effects of hydrodynamic sorting onto the suspended load geochemistry. The Amazon is the largest river of the world in terms of water discharge $\left(200,000 \mathrm{~m}^{3} \cdot \mathrm{s}^{-1}\right)$ [Molinier et al., 1996] and drainage area $\left(6.4\right.$ million $\left.\mathrm{km}^{2}\right)$. The flux of solids discharged to the ocean by the Amazon is between 500 and 1200 MT.yr $^{-1}$ [Meade et al., 1979; Dunne et al., 1998; Maurice-Bourgoin et al., 2007]. It is therefore a significant geological operator at the global scale. Finally, at the mouth, the Amazon River is a several kilometers wide, more than $50 \mathrm{~m}$ deep channel, allowing for a strong potential hydrodynamic differentiation of particles along the water column [Bouchez et al., 2010a]. River sediment samples were collected along depth profiles of the Solimões, Madeira and Amazon mainstreams, and characterized for chemical and isotopic ( $\mathrm{Sr}$ and $\mathrm{Nd}$ ) composition. These rivers show a clear chemical and isotopic stratification. The variation in element concentrations can be related to the grain size distribution of the transported material, hence to hydrodynamics. Chemical variations are partly caused by a dilution effect by quartz. The use of normalization diagrams allows us to show that dilution by quartz is not the sole process and that elements can be classified into different groups reflecting their geochemical properties during chemical weathering and transport in the Amazon Basin. The behavior of alkali elements (from $\mathrm{Na}$ to $\mathrm{Cs}$ ) is of particular interest since they show a gradual depletion/ enrichment pattern in the finest fractions from low to high atomic masses. Finally, the comparison between the Solimões and the Madeira basins 


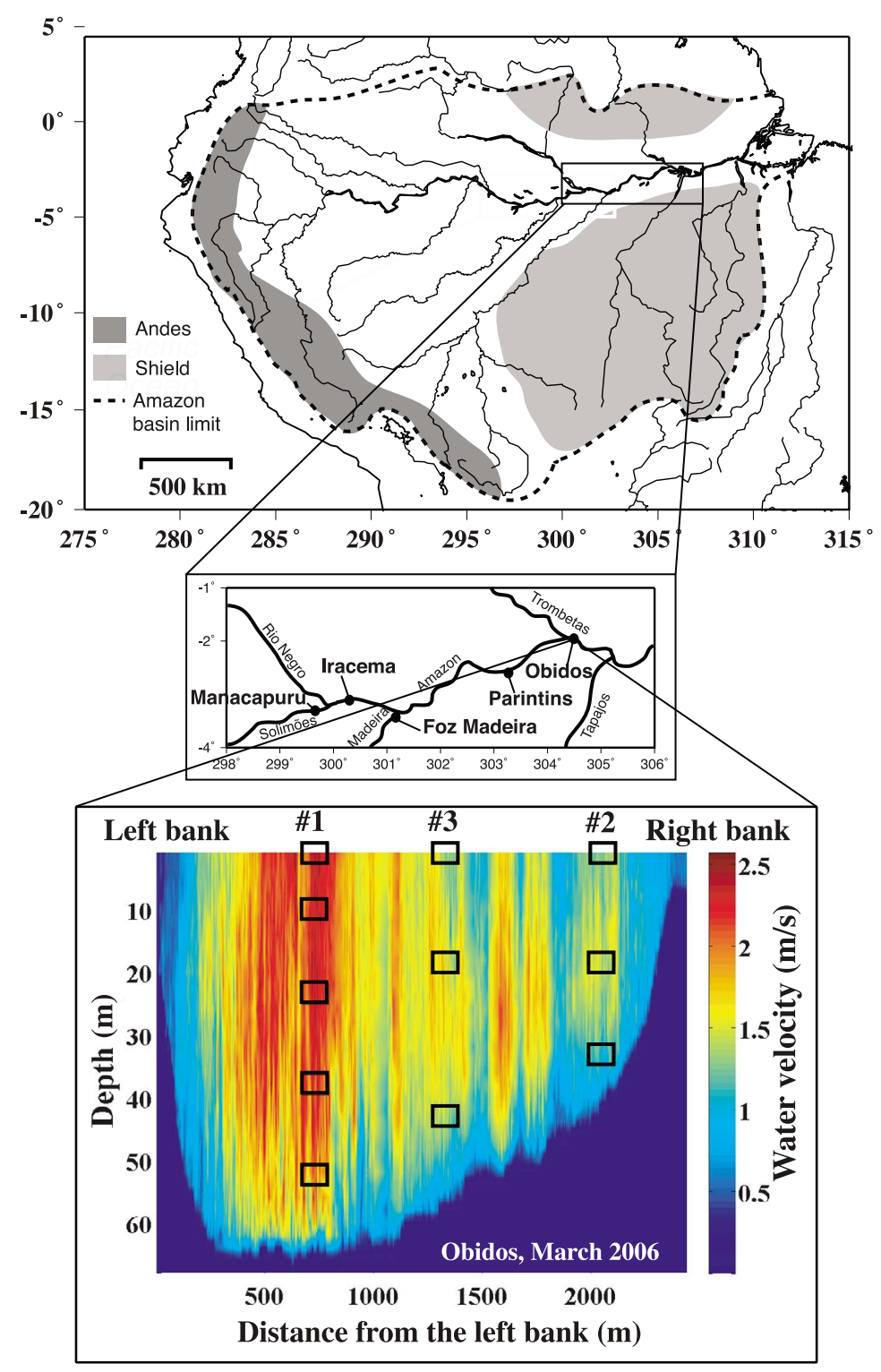

Figure 1. Map of the Amazon River basin and of the sampling sites of this study and ADCP transect obtained on the Amazon at Óbidos in March 2006. Rectangles indicate positions of the samples in the cross section.

provides insights into the relationships between weathering, sorting and crustal composition.

\section{Settings, Sampling, and Analytical Methods}

\subsection{The Amazon Basin}

[6] The Amazon River basin can be geologically and morphologically divided into four main units (Figure 1): the Andes, the two shields (the Brazilian Shield and the Guyana Shield), and the Amazon plain. This latter unit is itself formed of the Andes foreland and the Amazon Trough, where the mainstem flows between the two shields in the eastern part of the basin toward the Atlantic Ocean. Ninety percent of the sedimentary budget of the Amazon River at Óbidos, which is the last gauging station upstream of the delta, is accounted for by the Solimões and Madeira rivers [Gibbs, 1967]. The headwaters of these two rivers drain the actively eroding Andes, where mean elevation is ca. $3800 \mathrm{~m}$. The other large tributaries drain only lowland or relatively low-relief areas, such as the plain or the shields, and do not have high sediment loads [Stallard and Edmond, 1983]. This study is therefore 
focused onto the Amazon mainstem and the Solimões and the Madeira rivers. The Madeira River Andean tributaries mainly drain Ordovician-Silurian shales in the Central Cordillera and Cretaceous to early Cenozoic terrigenous sediments while flowing through the fold-and-thrust belt [Putzer, 1984]. These sedimentary units are thought to ultimately derive from the erosion and weathering of the Brazilian craton [Basu et al., 1990]. In addition to similar old sedimentary terranes (Paleozoic to Cenozoic shales and carbonates), the Solimões River basin incorporates a relatively recent component of subduction arc plutonic and volcanic rocks (Cenozoic to present) [Basu et al., 1990]. In both basins, the lowland rivers drain Tertiary to modern fluviolacustrine sediments, with a contribution of the Precambrian granulites of the Brazilian Shield in the Madeira lowland basin. The differences between these two basins will allow us to examine the importance of bedrock composition in the sorting processes affecting river sediments. The Amazon river system was sampled at five sites (Figure 1), in June 2005 and in March 2006: (1) at the mouth of the Solimões River, near the town of Manacapuru, (2) downstream from the Solimões-Negro confluence, near the town of Iracema, (3) at the mouth of the Madeira River, (4) downstream from the Amazon-Madeira confluence, near the town of Parintins, and (5) on the Amazon River near the town of Óbidos.

\subsection{Sample Collection}

[7] At each sampling location, Acoustic Doppler Current Profiler (ADCP, RD Instruments, frequency $600 \mathrm{kHz}$ ) [Filizola and Guyot, 2004] transects were conducted to obtain accurate water velocity profiles, river bottom depth measurements, and water discharge (Figure 1). Then, one to four vertical profiles of the river water column were sampled, distributed over the river cross section. Each of these vertical profiles consisted in two to five samples, distributed onto the vertical profile, from the top to the bottom of the river channel. Approximately 8 liters of river samples were taken by submerging a point-sediment sampler (HyBAm Project, http://www.ore-hybam.org) down to the desired sampling depth. Underpressure Teflon filtration units (PSE filter sheets, $0.22 \mu \mathrm{m}$ ) were used to filter the river water. Membranes were rinsed with a limited amount of filtered water. All suspended matter was removed from the filter membranes and then stored into tainted borosilicate glass bottles. In the lab, the bottles were decantated during several days, the supernatant pipetted out, and the remaining sediments dried at $50^{\circ} \mathrm{C}$. Bed sediments were also dredged from the bottom of the river, stored in plastic bags and dried in the lab at $50^{\circ} \mathrm{C}$. The sediments were finally transferred in a mortar and weighed. Fifty milligrams were kept aside for size distribution analysis, and the remaining sediments were finely crushed for mineralogical, chemical and isotopic analysis. Suspended matter concentrations were obtained by dividing the weight of recovered sediment from the filter sheet by the weight of recovered water from the sampler. The estimated relative uncertainty on SPM concentrations is $10 \%$.

\subsection{Analytical Methods}

[8] Samples, along with their main characteristics and analytical results are listed in Table 1. Noncrushed aliquots of dried sediments were dispersed into distilled water using ultrasonication, and size distribution analyses were made using a Malvern Mastersizer laser diffraction granulometer, at the Laboratoire d'Environnement et de Minéralurgie (LEM, Nancy, France). Relative standard deviation on the modal size of repeated analysis of the same samples allowed us to estimate an analytical reproducibility of $10 \%$ for the grain size distribution analysis. Major, minor and trace element concentrations in suspended sediments were measured at the Service d'Analyse des Roches et Minéraux (SARM, INSU facility, Vandoeuvre-ls-Nancy, France, analytical details available on http://helium. crpg.cnrs-nancy.fr/SARM), by ICP-OES and ICPMS, after alkali fusion. Uncertainties were lower than $3 \%$ for major elements, and lower than $10 \%$ for minor and trace elements. XRD data were obtained on a CuK- $\alpha$ diffractometer (Rigaku) at the École Normale Supérieure, Paris, France, using powdered aliquots. For isotopic analysis, ca. $50 \mathrm{mg}$ of dried powder were digested into a concentrated $\mathrm{HF}-\mathrm{HNO}_{3}$ mixture in Teflon bombs at $120^{\circ} \mathrm{C}$. The resulting solution was evaporated to dryness, and the residue was dissolved in a $\mathrm{H}_{3} \mathrm{BO}_{3}-\mathrm{HNO}_{3}$ mixture. After appropriate dilution, a few milliliters of the solution were loaded onto a Sr-SPEC (Eichrom) resin chromatography column to separate ca. $300 \mathrm{ng}$ of $\mathrm{Sr}$ [Birck, 1986]. Sr was then loaded onto a Re filament with a Ta-oxide activator and measured on a MCTIMS Triton (Thermo Electron) at the Institut de Physique du Globe de Paris, in dynamic mode, with typical signals of $3.5 \mathrm{~V}$ on mass $88\left(10^{11} \Omega\right)$. Mass discrimination was corrected using the invariant ratio ${ }^{88} \mathrm{Sr} /{ }^{86} \mathrm{Sr}(0.1194)$. Accuracy and reproducibility were tested through repeated analysis of the NBS standard SRM 987, that yielded a ${ }^{87} \mathrm{Sr} /{ }^{86} \mathrm{Sr}$ value of 0.71024 , with an external reproducibility 


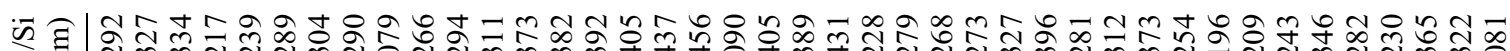

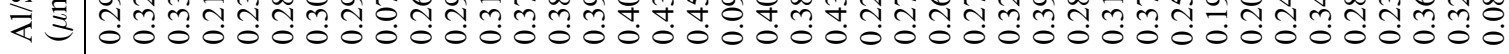

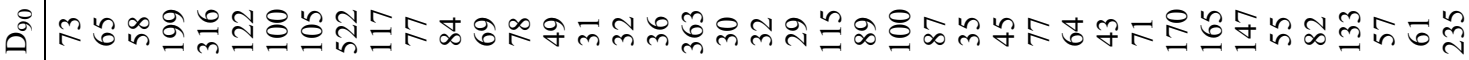

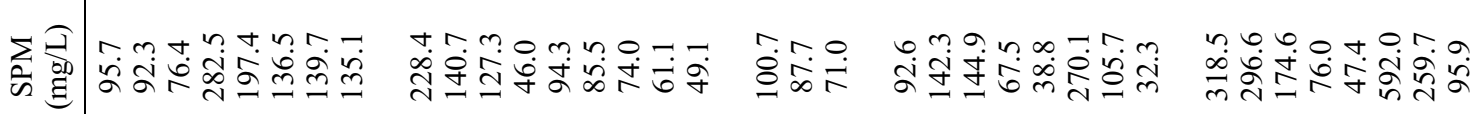

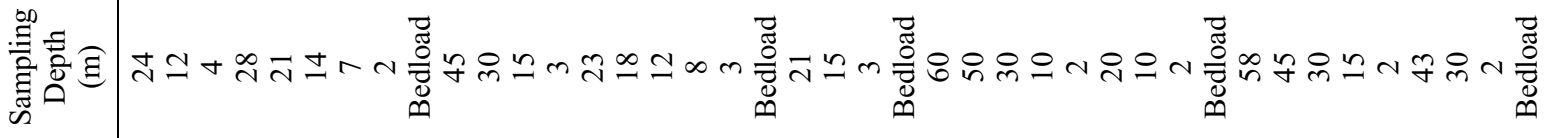

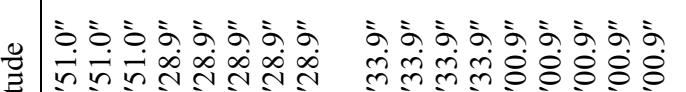

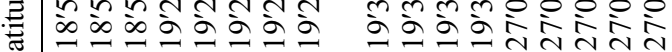

西

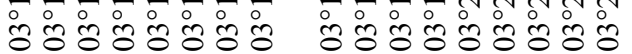

in

in in in in in in

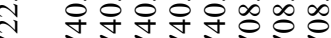

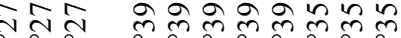

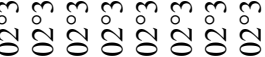

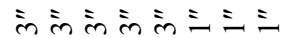

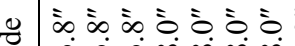

广广广广三三三三

कूष

อง

识

年

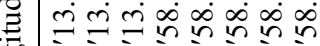

का लॉल लिल लि

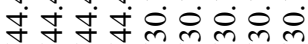

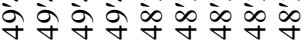

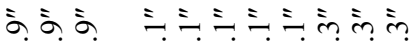

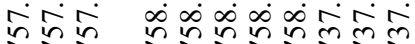

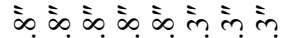

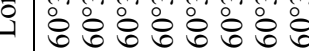

in

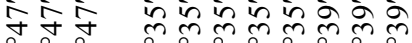

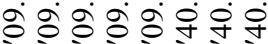

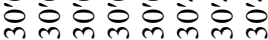

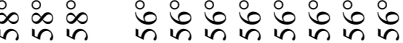

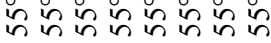

窟

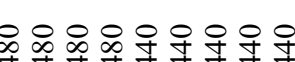

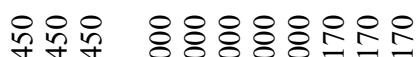

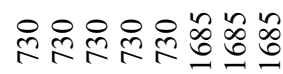

跑

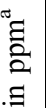

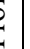

$-\pi-a d v a c$

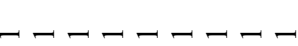

NaN

$--7-\pi \mathrm{n}$

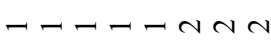

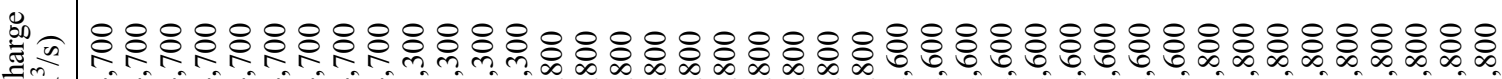

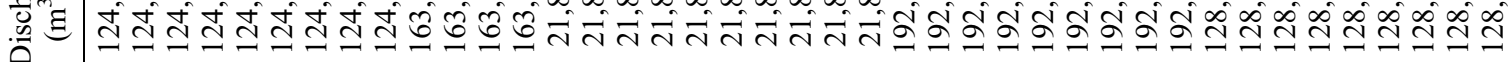

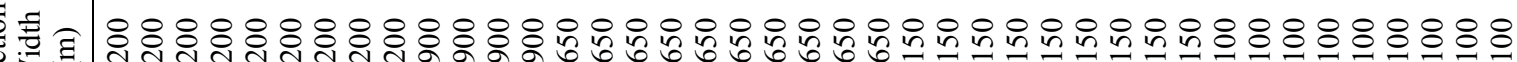

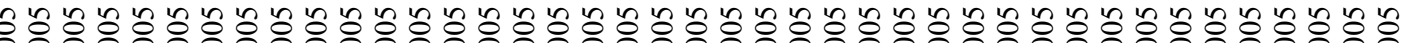

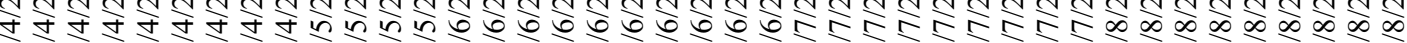

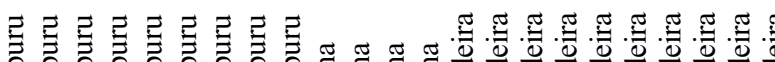




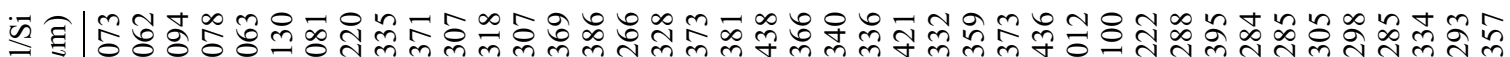

य

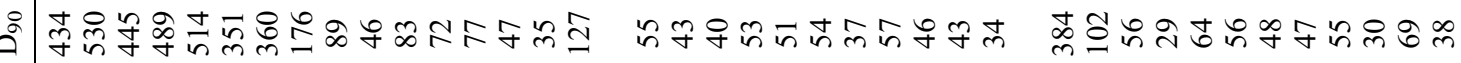

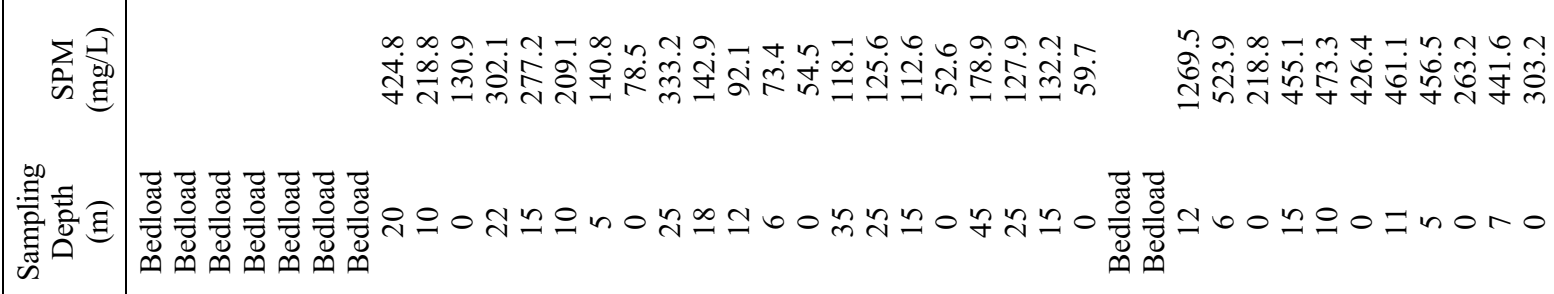

三三 $\quad$ क

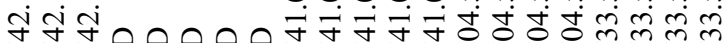

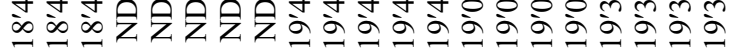

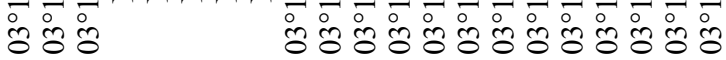

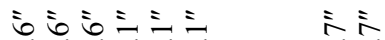
(a)

ò̀ ن

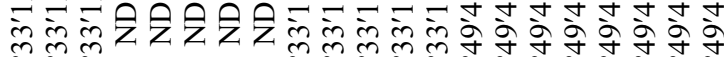

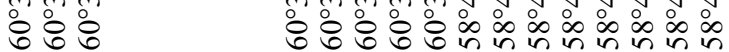

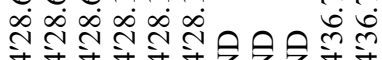

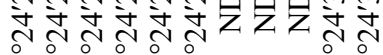

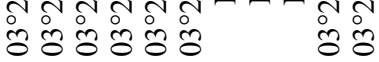

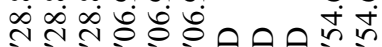

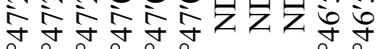

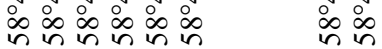
啇

荡

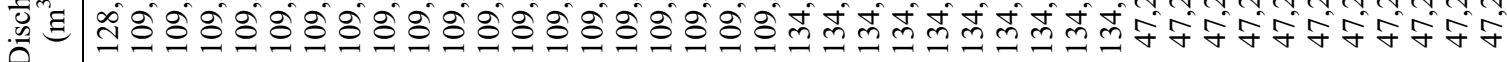

들

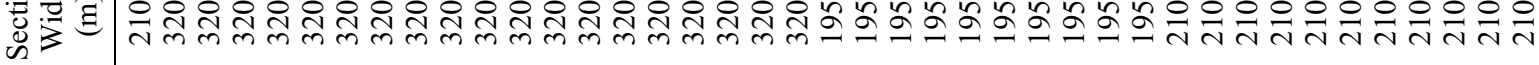

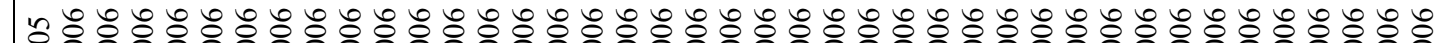

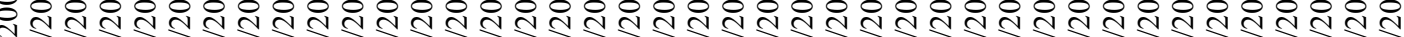

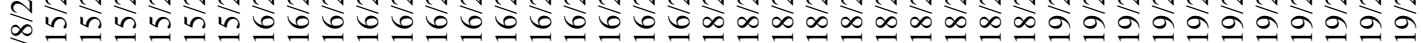

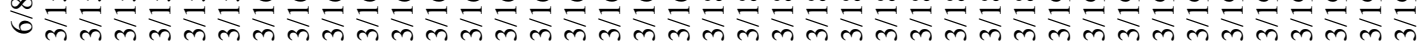

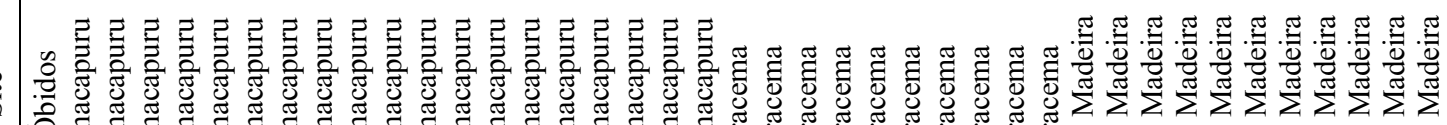

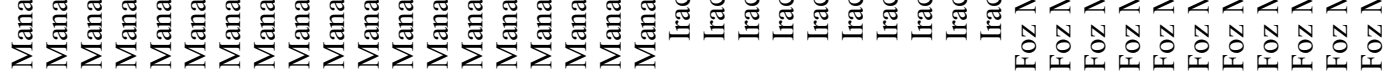

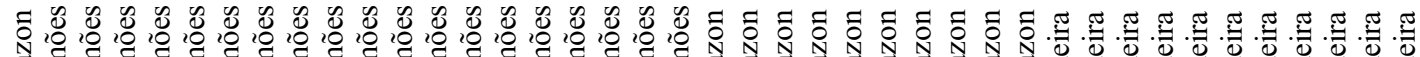

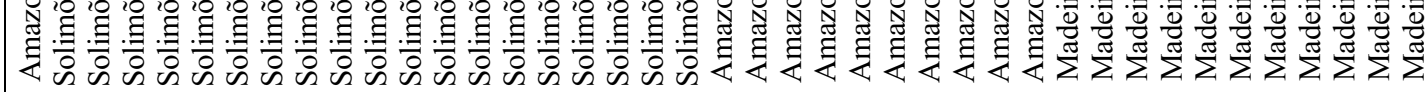

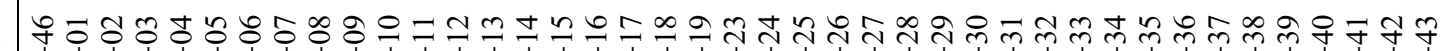

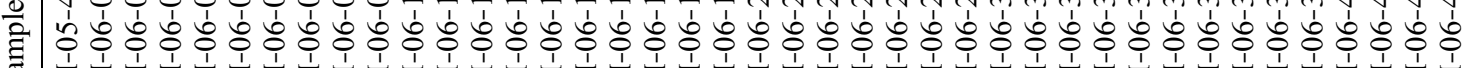

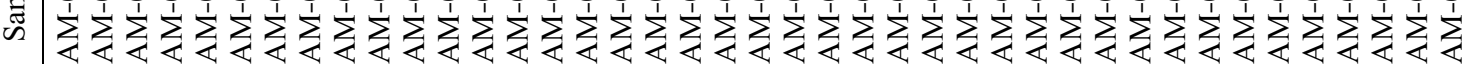




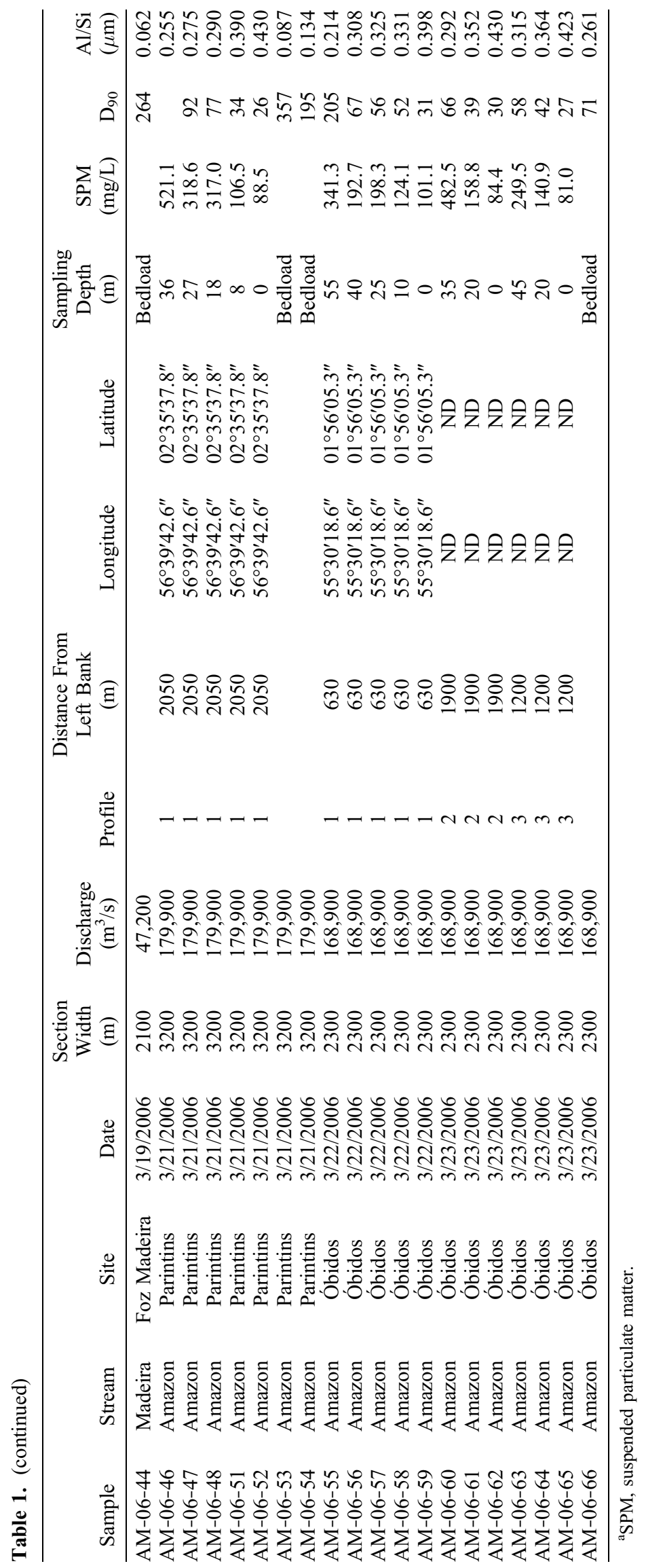


of $10^{-5}$ (relative $2 \sigma$ ). A few milliliters of the digested sediments solution were loaded onto a TRU-SPEC and then onto Ln-SPEC (Eichrom) resin columns, to separate REEs and then $\mathrm{Nd}$, respectively. $\mathrm{Nd}$ was measured in $3 \% \mathrm{HNO}_{3}$ solutions on a MC-ICPMS Neptune (Thermo Electron) at IPGP, in static mode. Typical signals on mass 142 were $8 \mathrm{~V}$. Mass discrimination was corrected using the invariant ratio ${ }^{146} \mathrm{Nd} /{ }^{144} \mathrm{Nd}(0.7219)$. Repeated analysis of an in-house standard (calibrated by TIMS on the La Jolla standard) gave accurate results with an external reproducibility of $10 \mathrm{ppm}$ (relative $2 \sigma$ ).

\section{Results}

\subsection{Concentration and Grain Size Distribution of Sediments}

[9] Results regarding suspended particulate matter (SPM) concentration and grain size distribution are reported and extensively discussed by Bouchez et al. [2010a]. A large increase of SPM concentration with sampling depth is observed in almost all of the vertical profiles, by a factor of up to five (Figures 2a and $2 \mathrm{~b}$ ). In the Solimões River, bed sediment samples are representative of the sand component, having a modal size of ca. $300 \mu \mathrm{m}$. This sand component is also visible in the deepest suspended load samples, with a significant fining with decreasing depth (at $-28 \mathrm{~m}$ and $-21 \mathrm{~m}$ for the profile 2 in June 2005, Figure 2c). The silt component is dominant in all suspended load samples, with a modal size around $25 \mu \mathrm{m}$. In any sample, clays represent less than $3 \%$ of the sediment. In the Madeira, a more homogenous grain size pattern is observed, with overall finer grain size distributions than in the Solimões (Figure 2d). Silts, coarsening from 7 to $35 \mu \mathrm{m}$ from $0 \mathrm{~m}$ to $-12 \mathrm{~m}$, are clearly dominant in all suspended load samples, while sands are dominant only in the bed sediment sample. Clay proportion is approximately twice as high as in the Solimões.

[10] The downward increase of SPM concentration is accompanied by a broad pattern of grain coarsening (Figures 2c and 2d). In other words, the increase of SPM concentration with sampling depth is the largest for coarse grain size fractions, whereas fine grain size fractions display a rather constant concentration with depth (equation (1)). These observations agree with the results of sediment transport dynamics in a turbulent flow. Assuming the equilibrium between the downward flux of settling suspended particles and the upward flux of particles from the bed by turbulent dispersion, the predicted SPM concentration profile is [Rouse, 1950]

$$
\frac{C(z)}{C(a)}=\left(\frac{H-z}{z} \cdot \frac{a}{H-a}\right)^{Z_{R}}
$$

where $H$ is the channel depth, $z$ is the height above river bed and $a$ is a reference height above bed, $C$ is the SPM concentration and $Z_{R}$ is the socalled Rouse number

$$
Z_{R}=\frac{w}{\kappa u^{*}}
$$

where $u^{*}$ is the shear bottom velocity, $\kappa$ the von Kármán constant [Garcia, 2008], and $w$ is the settling velocity of sediments. The lower term of the Rouse number $\left(\kappa u^{*}\right)$ reflects the intensity of the turbulent fluctuations of the flow velocity, and determine the ability of the flow to carry particles in suspension through turbulent diffusion. The upper term (the settling velocity $w$ ) indicates the ability of particles to settle down toward the bed, and the resulting enrichment at the bottom of the channel. Fast-settling (e.g., coarse and/or dense) particles will have high Rouse numbers (equation (2)) and will display a pronounced increase of concentration with depth (equation (1)). On the contrary, slow settling fine particles will have low Rouse numbers implying nearly constant SPM concentration with depth. Therefore, our observations concerning sediment grain size distribution and concentration are compatible with the Rouse model. These combined effects of size, density and shape of grains acting on their distribution throughout depth profiles are referred to in the following as hydrodynamic sorting during riverine transport. The Amazon vertical profiles of SPM concentration are well explained by the Rouse model, although Rouse numbers yielded by the analysis of these profiles are higher than calculated Rouse numbers from sediment grain size distribution and flow parameters [Bouchez et al., 2010a]. This discrepancy was attributed to particle aggregation in the river.

\subsection{Chemical Composition of Sediments}

\subsubsection{Chemical Composition Versus Depth}

[11] Chemical composition of the sampled sediments are listed in Table 2. Large variations are observed even in a single vertical profile. $\mathrm{Al}$ and $\mathrm{Si}$ concentrations in three vertical profiles sampled on the Solimões River in March 2006 are shown in Figure 3 for example. Si concentration increases with 

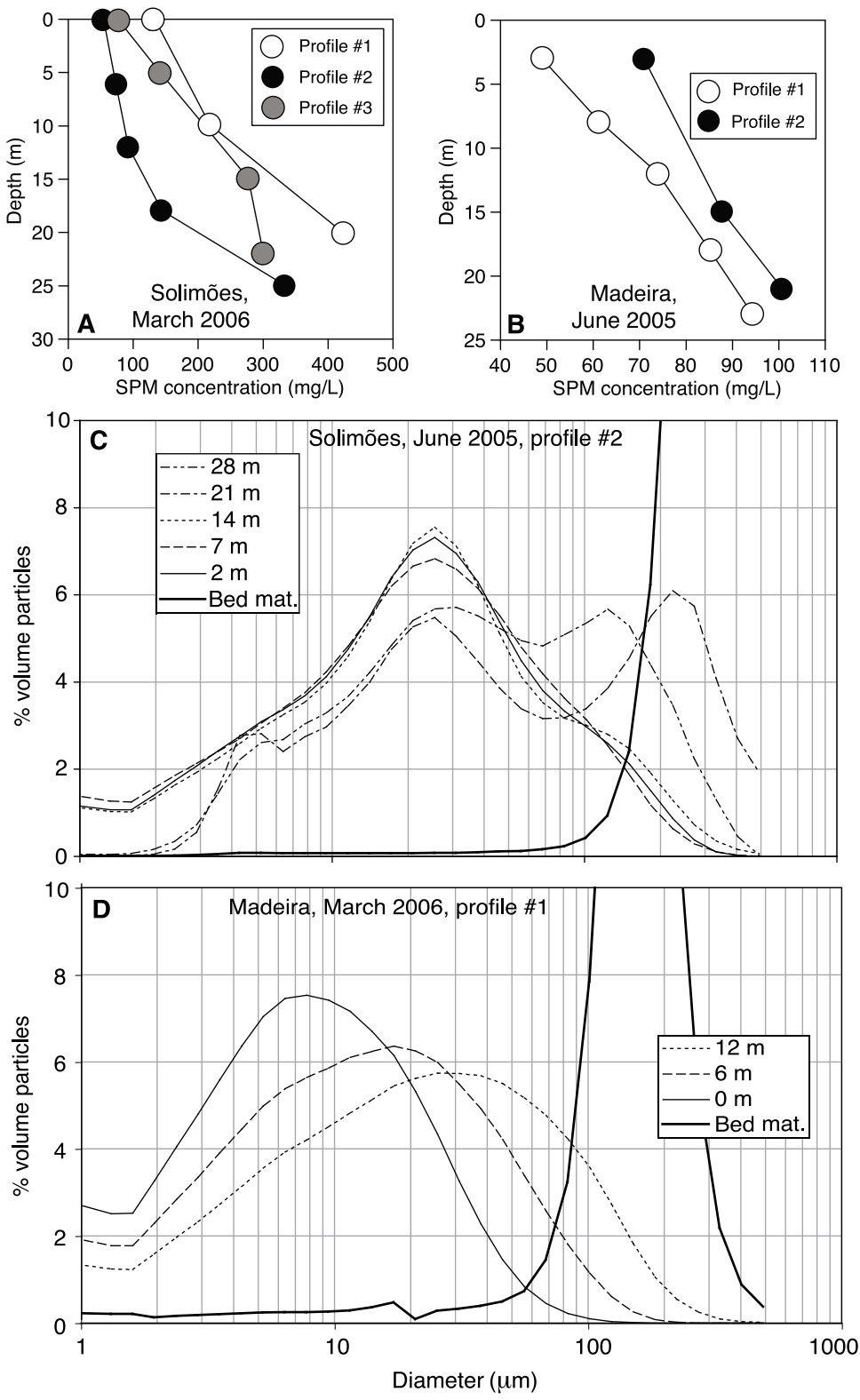

Figure 2. Representative suspended particulate matter (SPM) concentration depth profiles: (a) the Solimões River in March 2006, and (b) the Madeira River in June 2005. Representative grain size distributions in depth profiles: (c) the Solimões River in June 2005 and (d) the Madeira River in March 2006. See Table 1 for profiles and samples characteristics.

depth, typically from $260,000 \mathrm{ppm}$ to $300,000 \mathrm{ppm}$ (i.e., from 55 to $65 \mathrm{SiO}_{2}$ wt.\%), with concentrations reaching more than $400,000 \mathrm{ppm}$ in bed sediment samples $\left(85 \mathrm{SiO}_{2}\right.$ wt.\%). Al concentration decreases with depth: more than $100,000 \mathrm{ppm}$ to 70,000 80,000 ppm (i.e., 21 to $13-14 \mathrm{Al}_{2} O_{3}$ wt.\%), and is even more depleted in bed sediment samples. Similar trends are observed in the vertical profiles of other sampling sites. More generally, very large variations of elemental concentrations in sediments are observed for all elements over depth in single depth profiles (Table 2). These variations are almost as large as the site-to-site variations (for example, observed between the Madeira and Solimões rivers), and as large as the variations from one discharge stage to another (for example, Madeira in June 2005 and in March 2006).

\subsubsection{Link Between Grain Size Distribution and Chemical Composition of Sediments}

[12] Concentrations of $\mathrm{Al}$ and $\mathrm{Si}$ exhibit large and opposite variations in single depth profiles (Figure 3) 

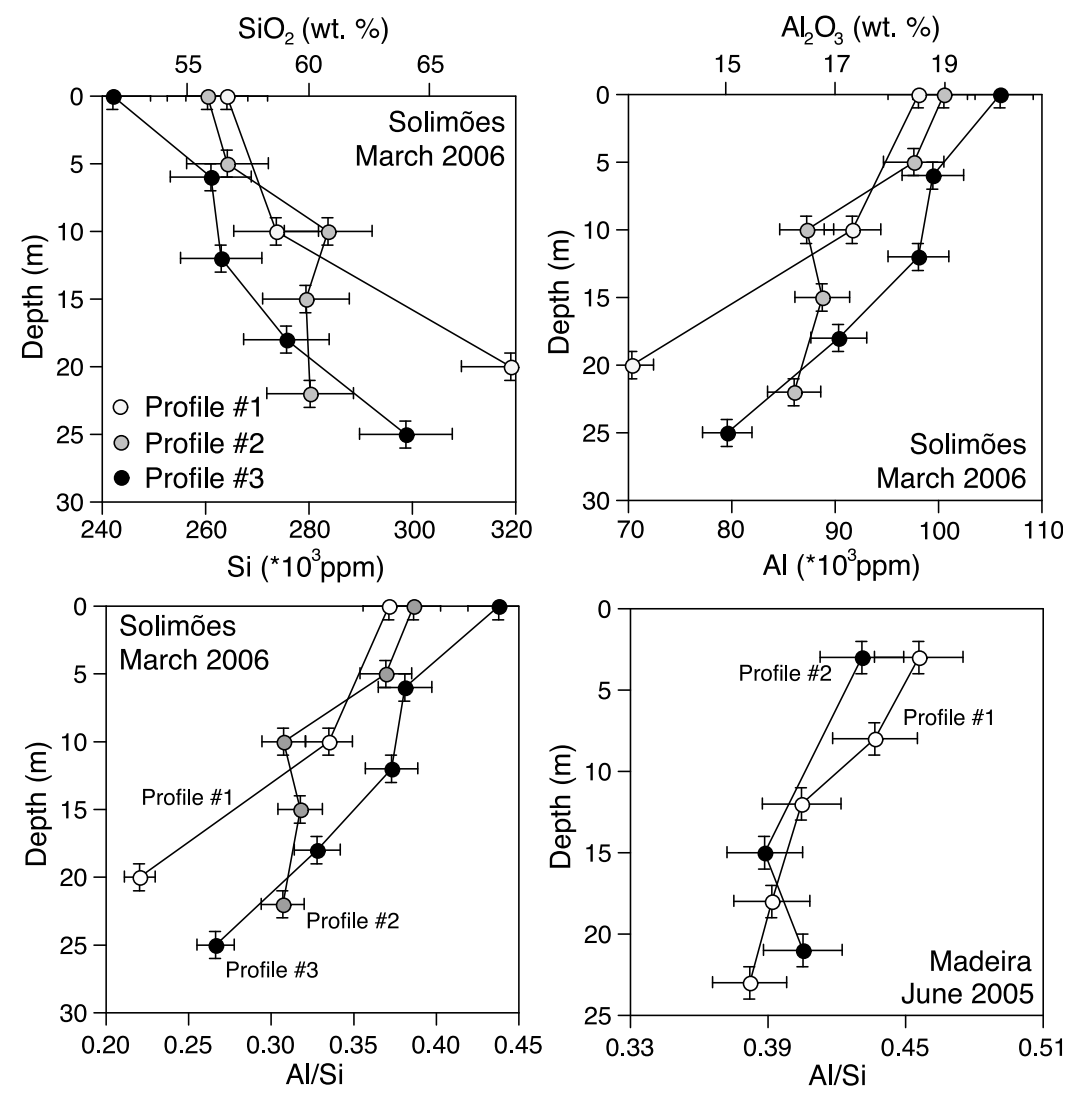

Figure 3. Concentration of $\mathrm{Si}$ and $\mathrm{Al}$ in suspended sediments versus depth in the Solimões River, March 2006. Al/Si versus depth in the Solimões and Madeira rivers (weight ratio). White, grey, and black symbols represent samples from profiles 1,2, and 3, respectively. See Table 1 for profiles and samples characteristics.

making the $\mathrm{Al} / \mathrm{Si}$ weight ratio a good proxy of vertical chemical differentiation. In the sediments of the Amazon Basin rivers, a relationship is observed between the $\mathrm{Al} / \mathrm{Si}$ ratio and the grain size distribution $\mathrm{D}_{90}$ (see Table 2 and Figure 4). $\mathrm{D}_{90}$ is the grain size below which $90 \%$ of the grains are found in a given sample. $\mathrm{D}_{90}$ is an interesting metric for grain size distribution since it integrates the whole size spectrum and the different granulometric components, independently of the number of modal sizes, for instance.

[13] The relationship of Figure 4 shows a tight link between grain size distribution and chemical composition of suspended sediments: coarse samples are Si enriched, while fine samples are Al rich. The Solimões, Madeira and Amazon rivers do not display significantly different grain size- $\mathrm{Al} / \mathrm{Si}$ relationships, despite different grain size distribution patterns (section 3.1).

[14] The variation of $\mathrm{Al} / \mathrm{Si}$ as a function of depth along vertical profiles in the Solimões and Madeira rivers is shown in Figure 3. Similar patterns are observed in the Amazon mainstem sampling sites.
$\mathrm{Al} / \mathrm{Si}$ points toward low values (ca. 0.15 , siliconrich coarse sediments) in bottom suspended sediments and high values (ca. 0.45, aluminum-rich fine sediments) in surface suspended sediments. Such a relationship was observed in previous studies on the Ganga-Brahmaputra system by Galy et al. [2007, 2008]. Variations of the $\mathrm{Al} / \mathrm{Si}$ ratio of suspended sediments are also observed with sampling date. All the sediment samples from the Amazon River basin have a grain size and $\mathrm{Al} / \mathrm{Si}$ that result from a mixing between two end-members, best represented by bed sediments on one hand (coarse, low $\mathrm{Al} / \mathrm{Si}$ ) and surface suspended sediments on the other hand (fine, high $\mathrm{Al} / \mathrm{Si}$ ). These endmembers are referred hereafter to as coarse and fine, respectively.

[15] Figure 4 demonstrates that despite the large temporal and spatial variations of sediment grain size, $\mathrm{Al} / \mathrm{Si}$ and grain size always vary consistently. For example, during the Madeira low-water stage (June 2005), suspended sediment samples display higher $\mathrm{Al} / \mathrm{Si}$, because coarse, high-Rouse number, Si-rich sediments are less readily transported high 


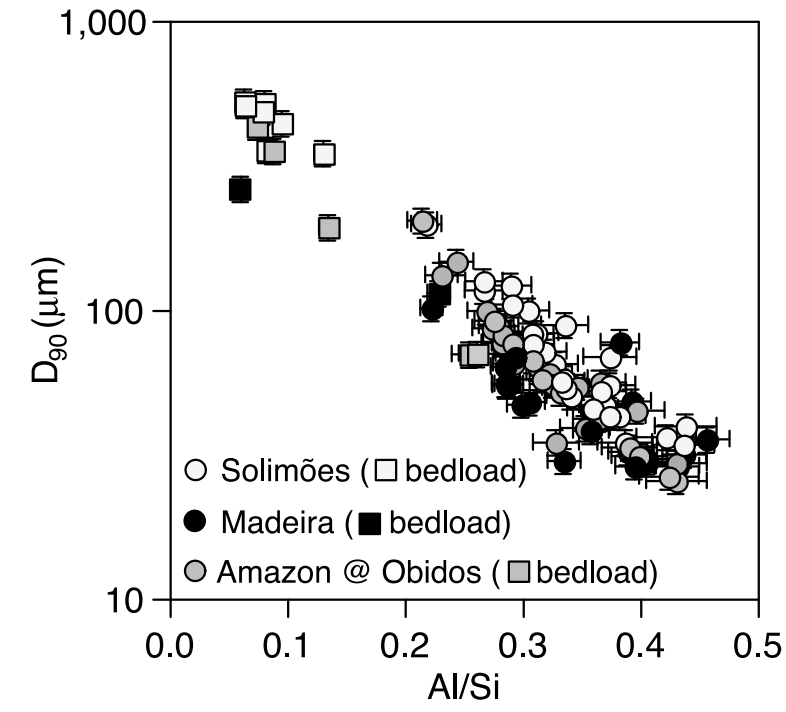

Figure 4. Relationship between $\mathrm{D}_{90}$ and $\mathrm{Al} / \mathrm{Si}$, for all samples. White symbols represent Solimões River and the Amazon River at Iracema, black symbols represent Madeira River, and grey symbols represent Amazon River at Parintins and at Óbidos. Bedload samples are represented by squared symbols, and suspended load samples are represented by circles.

in the water column under these rather slow flow conditions than during high-water stage. Lowwater stage samples thus plot in the bottom right corner of the $\mathrm{D}_{90^{-}}-\mathrm{Al} / \mathrm{Si}$ diagram. High-water stage samples have both higher $\mathrm{D}_{90}$ and lower $\mathrm{Al} / \mathrm{Si}$, and will plot closer to the top left corner of the diagram. However, all these sediments plot on the same line in the $\mathrm{D}_{90}-\mathrm{Al} / \mathrm{Si}$ diagram.

[16] The $\mathrm{Al} / \mathrm{Si}$ ratio is thus a surrogate for grain size. In the following, chemical and isotopic compositions are examined as a function of $\mathrm{Al} / \mathrm{Si}$, rather than sampling depth, allowing for a chemical study of the whole size spectrum of river sediments.

\subsubsection{Chemical Composition Versus Al/Si Ratio}

[17] Chemical composition of surface sediment samples are comparable with previous studies on the Amazon River [Gibbs, 1967; Gaillardet et al., 1997; Elbaz-Poulichet et al., 1999; Viers et al., 2008]. The Amazon at Iracema exhibits the same concentrations as the Solimões, since the Rio Negro does not contribute significantly to the Amazon sedimentary budget [Gibbs, 1967]. Downstream from the Madeira-Amazon confluence (at Parintins and Óbidos), the Amazon has intermediate values of chemical concentrations, well explained by a mixing between the two tributaries.
[18] The concentration of $\mathrm{Si}$ is negatively related to the $\mathrm{Al} / \mathrm{Si}$ ratio, with bed sediment samples having the highest concentrations, whereas Al concentration displays the inverse behavior (Table 2). The Amazon, Solimões and Madeira rivers define a single relationship, which is probably due to the fact that the abundances of these major elements do not vary from a bedrock to another at the large catchment scale.

[19] Concentrations of Th and REEs (Figure 5 for Th) display a linear positive relationship with $\mathrm{Al} / \mathrm{Si}$. One bed sediment sample from the Madeira clearly lies outside of the general trend and is very enriched in Th and REEs. The Solimões and Amazon mainstem display similar relationships for Th and REEs concentrations and $\mathrm{Al} / \mathrm{Si}$. The Madeira River is enriched in Th and REEs compared to the Solimões for a given $\mathrm{Al} / \mathrm{Si}$ value.

[20] Transition metals (Cr, Fe, $\mathrm{Co}, \mathrm{Cu}, \mathrm{Zn}$ ) follow a clear increase in concentration with increasing $\mathrm{Al} / \mathrm{Si}$ (although two possibly contaminated samples display very high concentrations of $\mathrm{Cu}$, Table 2). No significant difference was found between the different rivers.

[21] Concentrations of $\mathrm{Zr}$ and $\mathrm{Hf}$ decrease with increasing $\mathrm{Al} / \mathrm{Si}$ (Figure 5 for $\mathrm{Zr}$ ), except for the lowest $\mathrm{Al} / \mathrm{Si}$-suspended load samples of the Solimões River. Some bed sediment samples are highly enriched in $\mathrm{Zr}$ and $\mathrm{Hf}$. Ti, $\mathrm{Nb}$ and Ta concentrations increase with increasing $\mathrm{Al} / \mathrm{Si}$. Then, these concentrations slightly decrease with increasing $\mathrm{Al} / \mathrm{Si}$ for $\mathrm{Al} / \mathrm{Si}$ values above 0.35 . The relationships are different for the two tributaries, except at high $\mathrm{Al} / \mathrm{Si}$.

[22] In suspended load samples, Na concentration decreases with increasing $\mathrm{Al} / \mathrm{Si}$ (Figure 5), while in bed sediment samples, $\mathrm{Na}$ decreases with decreasing $\mathrm{Al} / \mathrm{Si}$. These two trends result in a bellshaped curve of $\mathrm{Na}$ concentrations as a function of $\mathrm{Al} / \mathrm{Si}$. The variability observed in the bed sediment samples is as large as the one observed for the suspended load samples. Conversely, $\mathrm{K}, \mathrm{Rb}, \mathrm{Cs}, \mathrm{Mg}$ and $\mathrm{Ba}$ increase with increasing $\mathrm{Al} / \mathrm{Si}$ in all rivers (Figure 5 for $\mathrm{K}, \mathrm{Cs}$ and $\mathrm{Mg}$ ), bed sediment samples lying on the same trend as suspended load samples. Relationships are different between the Solimões and Madeira rivers. $\mathrm{Ca}$ and $\mathrm{Sr}$ concentrations in the Solimões decrease in the suspended load with increasing $\mathrm{Al} / \mathrm{Si}$, and decrease in bed sediment samples with decreasing $\mathrm{Al} / \mathrm{Si}$, similarly to $\mathrm{Na}$. In the Madeira River, $\mathrm{Ca}$ and $\mathrm{Sr}$ increase with increasing $\mathrm{Al} / \mathrm{Si}$. 

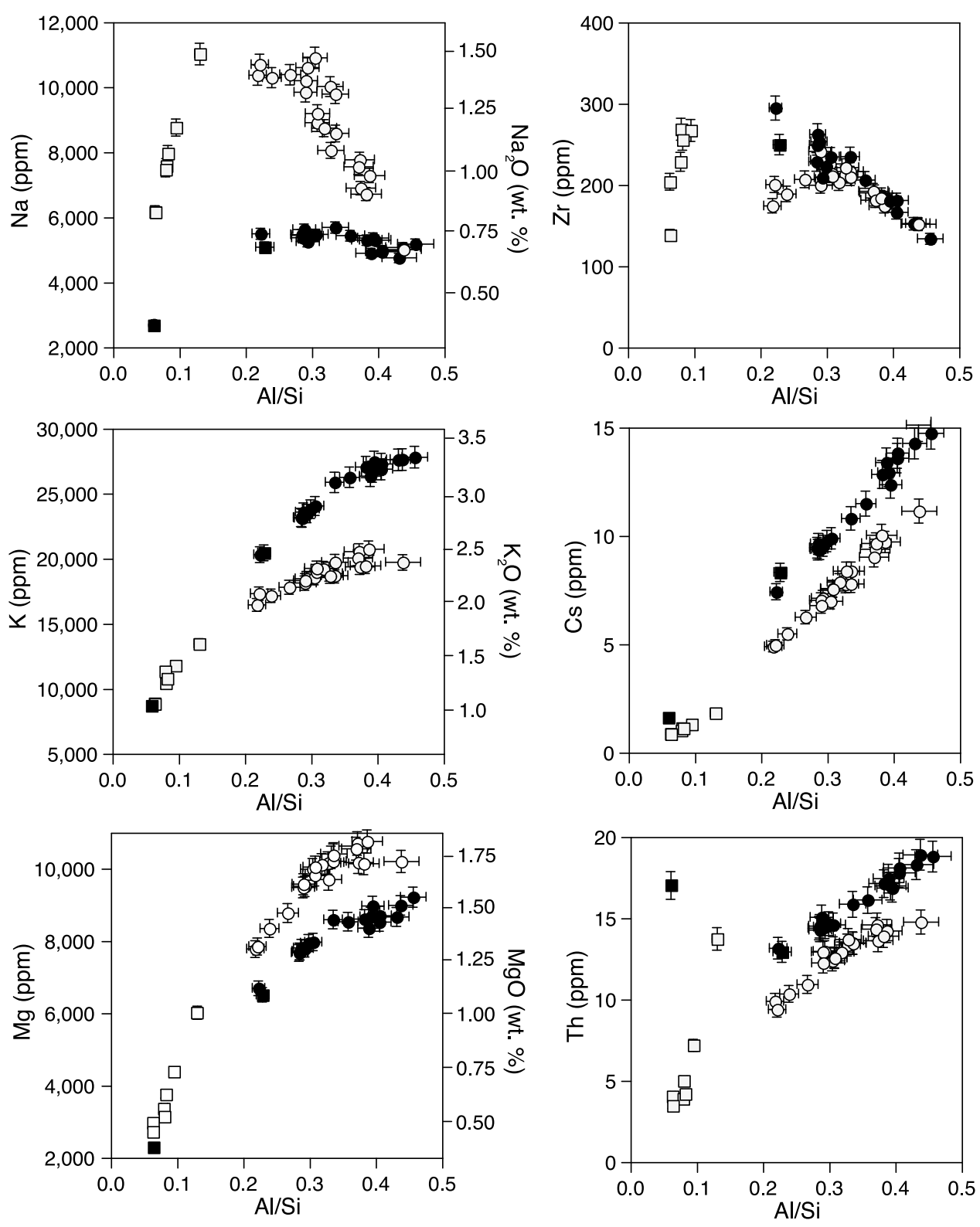

Figure 5. Th, $\mathrm{Zr}, \mathrm{Na}, \mathrm{K}, \mathrm{Cs}$, and $\mathrm{Mg}$ concentrations in the particulate phase versus $\mathrm{Al} / \mathrm{Si}$. White symbols represent Solimões River; black symbols represent Madeira River. Bedload samples are represented by squared symbols, and suspended load samples are represented by circles.

[23] To summarize, the above relations describe how element concentrations vary as a function of grain size in the particulate load of the Amazon river system. For most of the elements, concentrations increase with decreasing grain size (increasing $\mathrm{Al} / \mathrm{Si}$ ). This is particularly true for $\mathrm{Al}, \mathrm{Fe} \mathrm{Th}, \mathrm{REEs}, \mathrm{K}, \mathrm{Rb}$, $\mathrm{Cs}, \mathrm{Mg}$ and transition metals. It is interesting to note that this group contains elements classically known as soluble elements (mobile during water-rock interactions, and partitioned between solid and dissolved phase) [Dupré et al., 1996] and insoluble elements (nonmobile and transported essentially in the solid load). Si, Zr, Hf, Ti, Nb, Ta, Na, Ca, Ba and $\mathrm{Sr}$ show decreasing concentrations (at least in the suspended load) with decreasing grain size. Generally, these relations are not dependent upon the water stage for a given river. However, for most elements different correlations are defined for each river, the relationships between element concentrations and $\mathrm{Al} / \mathrm{Si}$ differing between the Solimões and the Madeira. For a given $\mathrm{Al} / \mathrm{Si}$ ratio, concentrations of Th, REEs, $\mathrm{K}, \mathrm{Rb}$ and $\mathrm{Cs}$ are higher in the Madeira River than in the Solimões River while $\mathrm{Na}, \mathrm{Ca}$ and $\mathrm{Mg}$ are lower in the Madeira. 


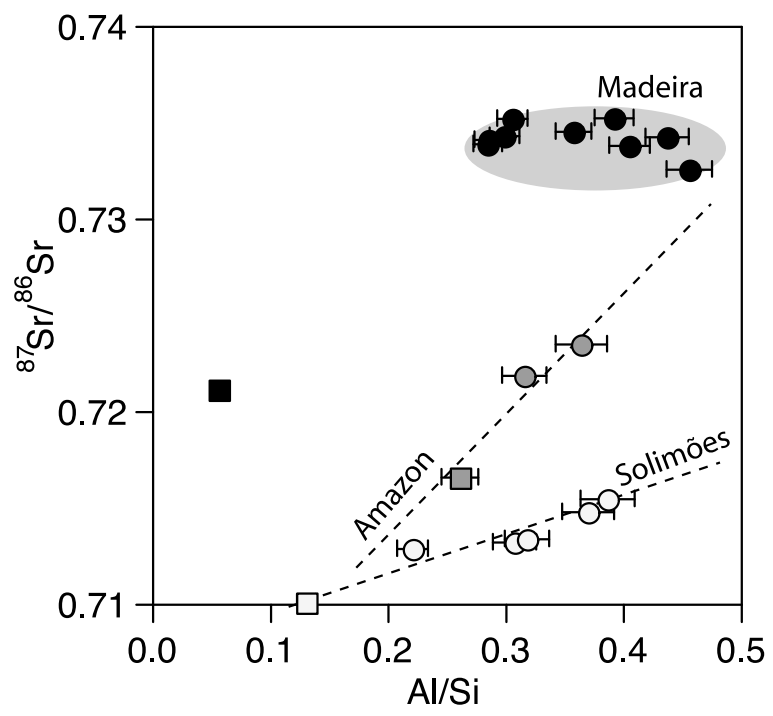

Figure 6. Sr isotopic ratios versus $\mathrm{Al} / \mathrm{Si}$. White, black, and grey symbols represent Solimões, Madeira, and Amazon (at Óbidos) samples, respectively. Bedload samples are represented by squared symbols, and suspended load samples are represented by circles.

[24] Altogether, these observations clearly indicate that the change in chemical composition of suspended sediments throughout depth in a single river channel, observed for instance in Figure 3, is related to a change in grain size, which is in turn induced by hydrodynamic sorting. Therefore, chemical elements are greatly and variably affected by hydrodynamic sorting processes in the river channel.

\subsection{Sr and Nd Isotopic Ratios}

[25] $\mathrm{Sr}$ isotopic ratios have been determined for some of the suspended load and bed sediment samples (Table 3). The values we obtain agree well with results reported by Goldstein and Jacobsen [1988], Allègre et al. [1996], and Viers et al. [2008]. Mean values for the Solimões River are ca. 0.713, whereas for the Madeira River more radiogenic values around 0.733 are obtained. These numbers are consistent with the occurrence of relatively young magmatic provinces in the Solimões drainage basin. Large variations of $\mathrm{Sr}$ isotopic ratios are observed in the Solimões River: more than $2 \times$ $10^{-3}$ for the suspended load, and nearly $5 \times 10^{-3}$ if the bed sediment sample is taken into account. In the Madeira River, the variation of ${ }^{87} \mathrm{Sr} /{ }^{86} \mathrm{Sr}$ within the suspended load is less than $10^{-3}$, although the measured ${ }^{87} \mathrm{Sr} /{ }^{86} \mathrm{Sr}$ for the Madeira bed sediment sample is more than $10^{-2}$ below the mean value of the suspended load.
[26] For the Solimões and the Amazon at Óbidos, significant positive correlations are observed between $\mathrm{Al} / \mathrm{Si}$ and ${ }^{87} \mathrm{Sr} /{ }^{86} \mathrm{Sr}$ (Figure 6). Similarly, Douglas et al. [1995] reported increasing ${ }^{87} \mathrm{Sr} /{ }^{86} \mathrm{Sr}$ with decreasing grain size in size-fractionated suspended sediments of the Murray River. No relationship is observed between ${ }^{87} \mathrm{Sr} /{ }^{86} \mathrm{Sr}$ and $\mathrm{Al} / \mathrm{Si}$ for the Madeira River, at least concerning suspended load. However, the analyzed bed sediment sample, which displays a very low $\mathrm{Al} / \mathrm{Si}$, is less radiogenic than the suspended load samples, similar to what is observed in the Solimões River.

[27] $\mathrm{Nd}$ isotopic ratios are presented in Table 3. The observed variability is low compared to Sr isotopic ratios, and the results agree well with previously reported data by Goldstein et al. [1984], Goldstein and Jacobsen [1988], Allègre et al. [1996], and Viers et al. [2008], with typical $\epsilon_{N d}$ values of -8 for the Solimões, 12 for the Madeira (except for one sample) and -10 for the Amazon at Óbidos. Significant variations with depth, or $\mathrm{Al} / \mathrm{Si}$ are observed between samples of a given river. The range of $\mathrm{Nd}$ isotopic ratios covered by the Solimões and Amazon suspended load samples is $2 \epsilon_{N d}$ units, and is $3 \epsilon_{N d}$ units for the Madeira. Bed sediment samples have higher ratios from suspended load samples in the Solimões and in the Amazon (6 and $2 \epsilon_{N d}$ units higher than the suspended load, respectively), but not in the Madeira. For the Solimões River, a significant decreasing trend of $\epsilon_{N d}$ is observed as a function of $\mathrm{Al} / \mathrm{Si}$. For the Madeira River, $\epsilon_{N d}$ shows no trend with $\mathrm{Al} / \mathrm{Si}$.

[28] The above isotopic data demonstrate that significant fractionations of $\mathrm{Nd}$ and especially $\mathrm{Sr}$ isotopes occur along depth profiles. This is particularly true for the Solimões River. These results show that the common assumption that suspended sediments in large rivers are isotopically homogenous from surface to bottom is not correct.

\section{Discussion}

\subsection{Behavior of Chemical Elements With Respect to Hydrodynamic Sorting in the Amazon River: The Fan-Shaped Diagram}

\subsubsection{Dilution of Chemical Concentration by Quartz and Normalization to Th}

[29] As shown above, concentrations of most elements decrease with decreasing $\mathrm{Al} / \mathrm{Si}$. Dilution by a phase with low concentration of these elements can explain this observation. Potential candidates 
are quartz and organic matter. Because organic carbon concentration in Amazon sediments is relatively low (of the order of 1\%) [Hedges et al., 1986], organic matter cannot account for the extent of dilution observed for elements such as Al, Fe, REEs and $\mathrm{Th}$ at low $\mathrm{Al} / \mathrm{Si}$. Hence, the amount of quartz in the samples is the main factor controlling the concentration of these elements throughout the sampled depth profiles. The decrease of the $\mathrm{Al} / \mathrm{Si}$ ratio at depth accompanying the decrease of most elemental concentrations, can thus be attributed to the hydrodynamic enrichment of relatively coarse quartz grains near the bottom of the channel, consistently with the observed coarsening of grain size distributions at depth (section 3.1). This feature, observed here in river sediments during their transport, was also reported for sand deposits and consolidated terrestrial sediments, for example. Low concentrations of most elements in sandstones compared to associated siltstones and shales have been reported by Cullers [1995] and Cullers et al. [1997] and have been attributed to higher quartz concentrations.

[30] This effect of dilution by quartz obscures further differential variabilities between chemical elements due to hydrodynamic sorting, and has to be corrected for. Elemental concentrations are thus normalized to Th concentration. Th is an insoluble element essentially carried by the solid phase in rivers. In order to represent all families of elements on the same diagram for a given river, Th-normalized concentrations are normalized to the mean value of the same elemental ratio in the suspended sediment samples of the considered river. In the following, these doubly-normalized concentrations are examined as a function of the $\mathrm{Al} / \mathrm{Si}$ ratio, used as an index of grain size. The resulting plot is called in the following the fan-shaped diagram (Figure 7), referring to the characteristic shape of these doubly Th-normalized ratios- $\mathrm{Al} / \mathrm{Si}$ relationships in that space.

[31] Here again, the pattern of the Amazon at Iracema is comparable to that of the Solimões at Manacapuru, and the Amazon mainstem at Parintins and Óbidos patterns are well explained by a "mixing" between the patterns of the Solimões and the Madeira rivers. Bed sediment samples show a significant scatter of the Th-normalized ratios, which can be attributed to local enrichment or depletion by selective entrainment of Th-bearing heavy minerals such as monazite [Slingerland, 1977], thus inducing normalizations artifacts. This is the reason why bed sediment samples are not represented in Figure 7. In the following, we first focus on the fan-shaped diagram of the Solimões.
Then, we will further examine the differences between the Madeira and the Solimões.

\subsubsection{Behavior of Insoluble Elements}

[32] Elemental ratios $\mathrm{Al} / \mathrm{Th}, \mathrm{Fe} / \mathrm{Th}$ and $\mathrm{REE} / \mathrm{Th}$ (as well as $\mathrm{Cu} / \mathrm{Th}, \mathrm{Cr} / \mathrm{Th}, \mathrm{Zn} / \mathrm{Th}$ and $\mathrm{Ga} / \mathrm{Th}$, not shown here) are rather constant with Al/Si (Figure 7). This means that increasing dilution by quartz toward low $\mathrm{Al} / \mathrm{Si}$ is the only process inducing a variation of concentration of these elements in suspended sediment with depth. Variations of Al, Fe, REEs, $\mathrm{Cu}, \mathrm{Cr}, \mathrm{Zn}$ and $\mathrm{Ga}$ concentrations in suspended sediments throughout the water column can thus be described by a two end-member mixture between fine, Al-rich grains that are enriched in suspended sediments near the surface of the channel, and quartz, enriched toward the bottom of the channel.

[33] However, a number of insoluble elements show nonhorizontal patterns in Figure 7. This means that their abundance is not only controlled by dilution by quartz of aluminous phases, but also by mixing between nonquartz minerals with contrasted concentrations of these elements. In the Amazon Basin rivers, $\mathrm{Si} / \mathrm{Th}, \mathrm{Ti} / \mathrm{Th}$ and $\mathrm{Zr} / \mathrm{Th}$ ratios (as well as $\mathrm{Co} / \mathrm{Th}$ and $\mathrm{Ge} / \mathrm{Th}$, not shown here) increase for decreasing $\mathrm{Al} / \mathrm{Si}$ ratios. $\mathrm{Nb}$ and $\mathrm{Ta}$ follow the same behavior as $\mathrm{Ti}$, and $\mathrm{Hf}$ follows that of $\mathrm{Zr}$. River bed sediment samples are particularly enriched in these elements. This feature, commonly observed in river systems [e.g., Albarède and Semhi, 1995; Garzanti et al., 2010b] is generally attributed to the enrichment of heavy minerals in this fraction. While $\mathrm{Si}$ is preferentially carried by quartz, $\mathrm{Ti}$ (with $\mathrm{Nb}$ and $\mathrm{Ta}$ ) and $\mathrm{Zr}$ (with $\mathrm{Hf}$ ) are probably carried by rutile and zircons, respectively. These so-called heavy minerals were all detected by XRD in the bed sediment samples (section 4.2), and are likely to be enriched near the bottom of the channel (thus in low $\mathrm{Al} / \mathrm{Si}$, coarse samples) by hydrodynamic sorting. It is interesting to notice that elements such as Th and REEs, which are likely to be significantly transported by heavy minerals such as monazite, do not show the same pattern as $\mathrm{Zr}$ and Hf. This surprising observation suggests that in the Amazon, these heavy minerals are not the primary carriers of Th and REEs in suspension.

[34] The abundance of insoluble elements in the Madeira, Solimões and Amazon rivers are thus controlled by a mixing between minerals differentially sorted within the river section. The bed and channel bottom suspended sediments are enriched in heavy minerals and quartz, while channel surface samples are enriched in clay minerals. Two major 

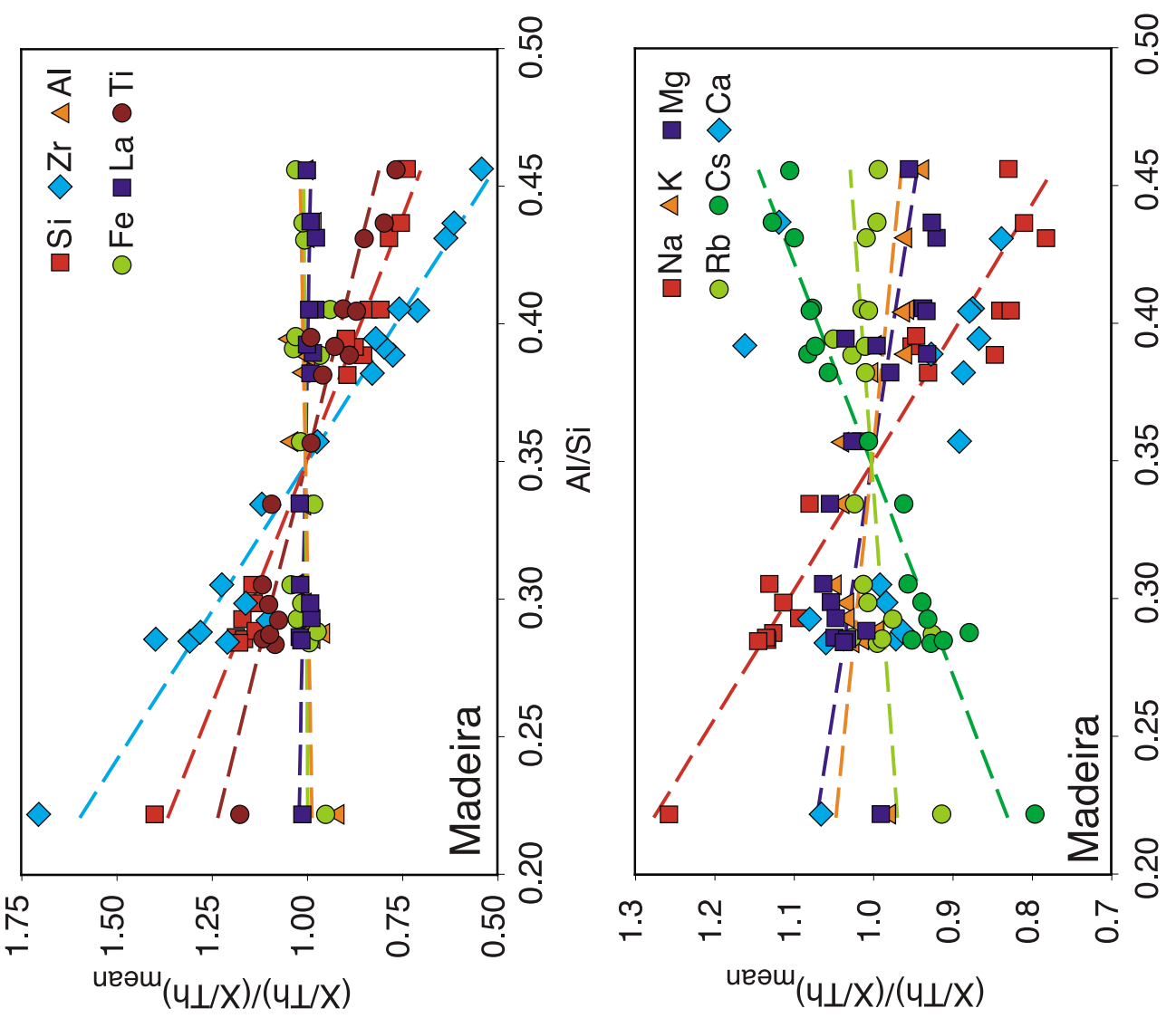

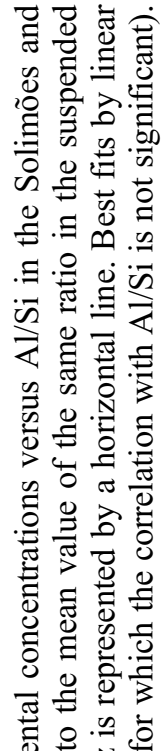

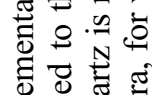

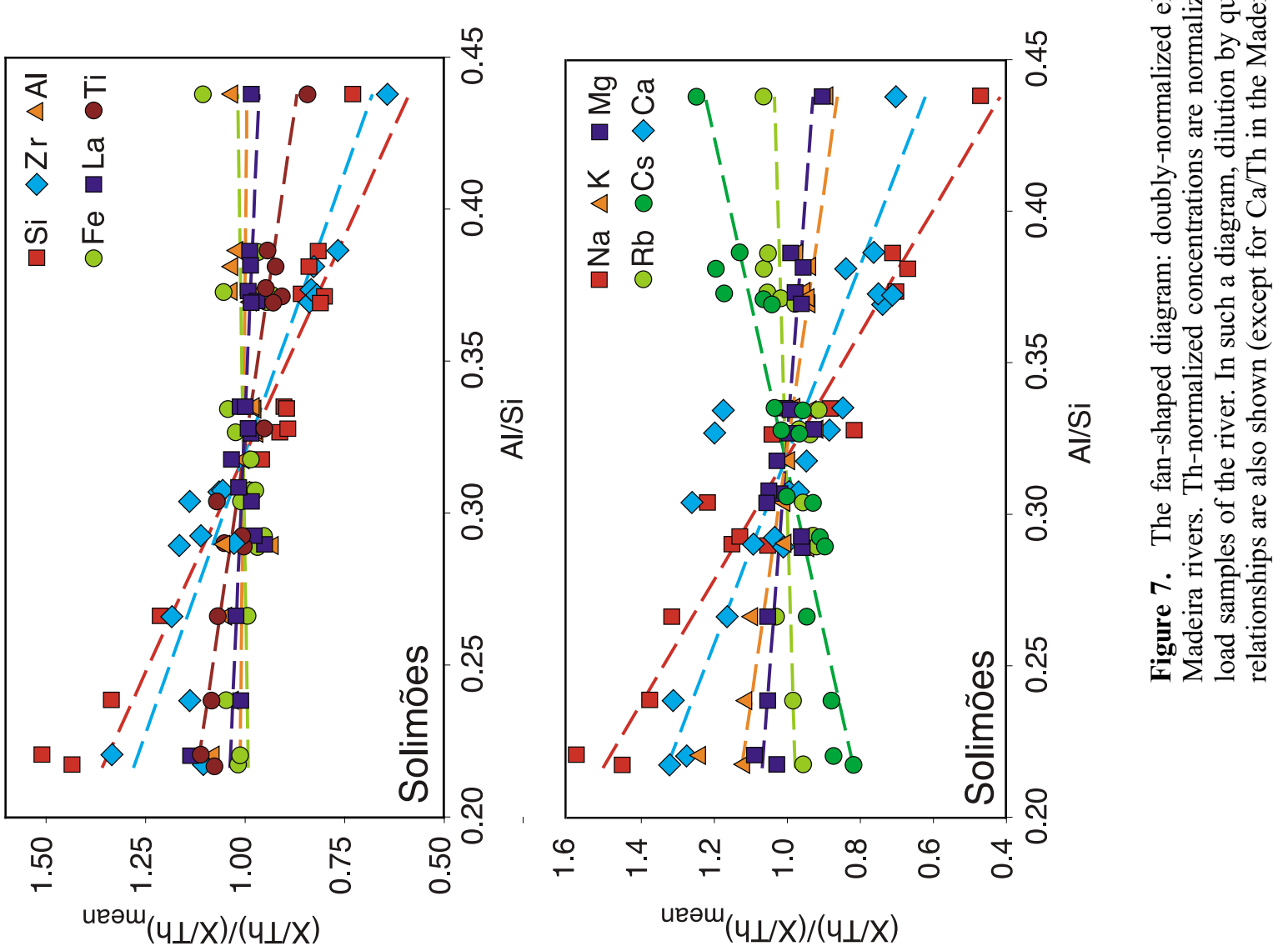



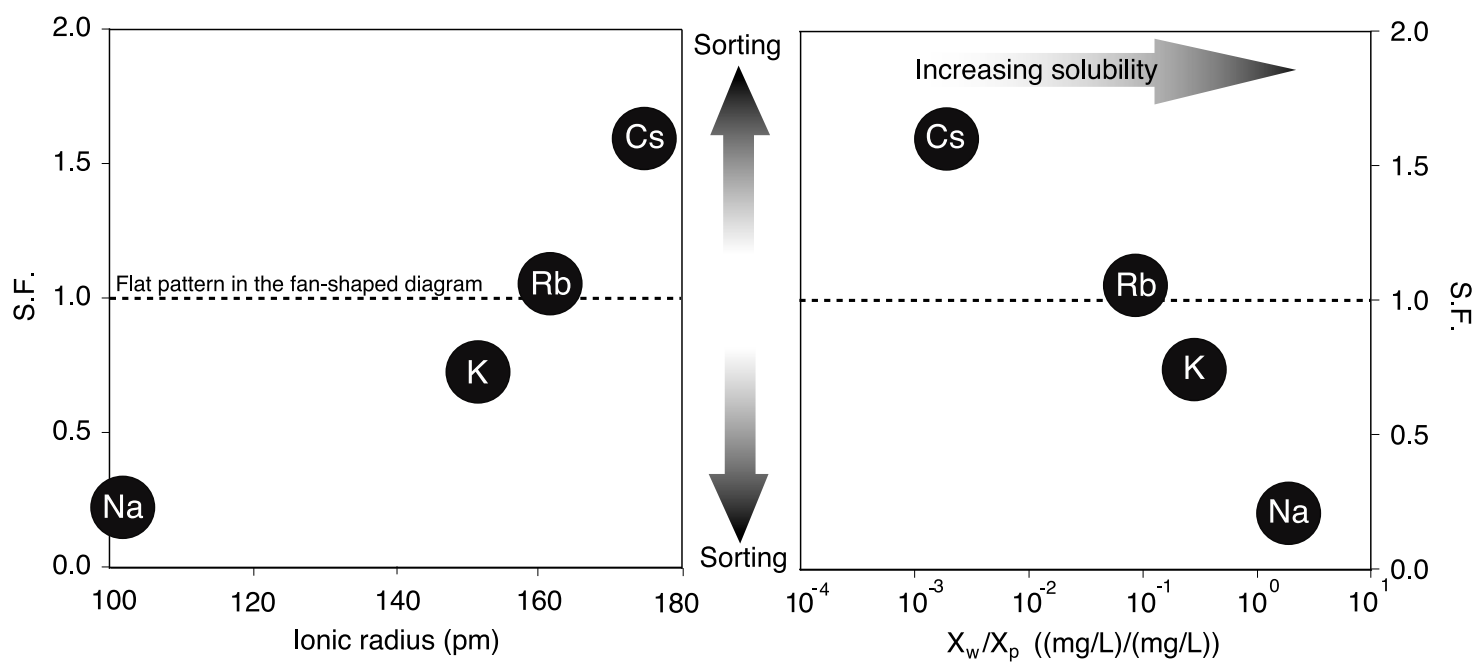

Figure 8. Sorting factor (S.F.) of alkali elements: (enrichment of alkali elements in the fine fraction of Solimões River suspended sediments, compared to the coarse fraction) as a function of ionic radius and solubility. S.F. is quantified using the $\mathrm{X} / \mathrm{Th}$ ratio of samples having a $\mathrm{Al} / \mathrm{Si}$ ratio of 0.45 (fine sediments), divided by the $\mathrm{X} / \mathrm{Th} \mathrm{ratio}$ of samples having a $\mathrm{Al} / \mathrm{Si}$ of 0.20 (coarse sediments).

types of insoluble elements can be distinguished: (1) the elements present in the Al-rich component dominating the channel surface samples, diluted with depth by quartz (and possibly other minerals relatively poor in those elements), and (2) the elements significantly carried by heavy minerals and quartz. We predict, according to the occurrence of various heavy minerals in a catchment area, that different patterns for insoluble elements in the fanshaped diagram should be observed for other river systems.

\subsubsection{Behavior of Alkali and Alkali-Earth Elements}

[35] Alkali ( $\mathrm{Na}, \mathrm{K}, \mathrm{Rb})$ and alkali-earth elements $(\mathrm{Mg}, \mathrm{Ca}, \mathrm{Sr}, \mathrm{Ba})$, referred to hereafter as $\mathrm{A}-\mathrm{AE}$, have been shown by many authors to be depleted in river surface sediments with respect to the continental crust [Dupré et al., 1996; Canfield, 1997; Gaillardet et al., 1997, 1999]. This depletion is due to their mobility during water-rock interactions. The chemical investigation of the depth profiles of the Amazon shed light on the behavior of A-AE during the weathering-erosion-transport process (see Figure 7 for $\mathrm{Na}, \mathrm{K}, \mathrm{Rb}, \mathrm{Cs}, \mathrm{Mg}$ and $\mathrm{Ca}$ ).

[36] 1. The doubly-normalized ratios of most A-AE vary with grain size. The fan-shaped diagram shows that the weathering intensity of particulates, which can be defined from the A-AE depletion compared to the source rock, is grain size dependent.
[37] 2. The coarsest material is enriched compared to the finest for $\mathrm{Na}, \mathrm{K}, \mathrm{Mg}$ and $\mathrm{Ca}$. $\mathrm{Rb}$, which has a fairly flat pattern, shows no enrichment in either end-member. Unlike any other A-AE, Cs is enriched in the fine end-member.

[38] 3. The heavier the alkali element, the more enriched (or the less depleted) in the fine-grained sediments, compared to the coarse-grained sediments. The extent of fractionation of a chemical element between different grain sizes can be quantified by the sorting factor S.F.

$$
\text { S.F. }=\frac{(\mathrm{X} / \mathrm{Th})_{\text {fine }}}{(\mathrm{X} / \mathrm{Th})_{\text {coarse }}}
$$

S.F. is related to the "slope" of the element pattern in the fan-shaped diagram (Figure 7): S.F. $=1$ means a flat pattern in the fan-shaped diagram and no fractionation of the element between fine and coarse sediments. Conversely, S.F. different from 1 means that the chemical element is undergoing fractionation due to sorting. We arbitrarily choose to use $\mathrm{Al} / \mathrm{Si}=0.20$ as representative of the coarse sediments, and $\mathrm{Al} / \mathrm{Si}=0.45$ for the fine sediments. Then, linear best fits in the fan-shaped diagram yield the corresponding $\mathrm{X} / \mathrm{Th}$ ratios and to calculate S.F. A very good correlation is obtained between S.F. and the ionic radius for alkali elements, as shown in Figure 8.

[39] 4. For alkali elements, the depletion/enrichment pattern is related to solubility, as shown in Figure 8, where S.F. for $\mathrm{Na}, \mathrm{K}, \mathrm{Rb}$ and $\mathrm{Cs}$ are plotted versus 
Table 2 (Sample). Chemical Element Concentrations in Amazon Samples ${ }^{\mathrm{a}}$ [The full Table 2 is available in the HTML version of this article]

\begin{tabular}{|c|c|c|c|c|c|c|c|c|c|c|c|c|c|}
\hline Sample & $\mathrm{Na}$ & $\mathrm{Mg}$ & $\mathrm{Al}$ & $\mathrm{Si}$ & $\mathrm{K}$ & $\mathrm{Ca}$ & $\mathrm{Ti}$ & $\mathrm{Cr}$ & $\mathrm{Fe}$ & $\mathrm{Co}$ & $\mathrm{Ni}$ & $\mathrm{Cu}$ & $\mathrm{Zn}$ \\
\hline AM-05-01 & 10,625 & 9528 & 85,373 & 291,961 & 18,513 & 11,143 & 4944 & 68 & 44,926 & 16.1 & 31.4 & 59.2 & 167 \\
\hline AM-05-02 & 10,038 & 10,176 & 89,704 & 274,671 & 18,894 & 13,364 & 5094 & 74 & 49,525 & 16.9 & 34.2 & 50.0 & 158 \\
\hline AM-05-03 & 9808 & 10,224 & 90,593 & 270,895 & 18,745 & 13,200 & 5094 & 71 & 50,960 & 16.7 & 32.7 & 51.7 & 160 \\
\hline AM-05-04 & 10,387 & 7794 & 69,358 & 319,256 & 16,488 & 10,921 & 4044 & 52 & 36,484 & 13.5 & 27.4 & 27.6 & 132 \\
\hline AM-05-05 & 10,313 & 8364 & 74,186 & 311,005 & 17,201 & 11,336 & 4248 & 56 & 39,277 & 14.2 & 40.6 & & 121 \\
\hline AM-05-06 & 9860 & 9498 & 84,081 & 290,607 & 18,172 & 10,907 & 4932 & 70 & 45,444 & 16.6 & 32.3 & & 143 \\
\hline AM-05-07 & 10,921 & 10,002 & 86,008 & 283,094 & 18,596 & 13,021 & 5004 & 69 & 45,423 & 16.6 & & & 135 \\
\hline AM-05-08 & 10,216 & 9588 & 84,341 & 290,701 & 18,355 & 11,164 & 4872 & 65 & 44,604 & 16.2 & 32.5 & 34.9 & 158 \\
\hline AM-05-10 & 7597 & 3390 & 31,071 & 390,964 & 10,480 & 6150 & 3204 & 32 & 21,273 & 7.5 & 14.8 & 4.5 & 41 \\
\hline AM-05-11 & 11,025 & 9372 & 79,888 & 300,211 & 17,840 & 11,514 & 4926 & 60 & 41,727 & 15.9 & 28.9 & 98.9 & 190 \\
\hline AM-05-12 & 10,291 & 9714 & 85,590 & 291,130 & 18,537 & 10,807 & 5022 & 65 & 44,303 & 16.9 & 31.4 & 47.6 & 156 \\
\hline AM-05-13 & 9920 & 9846 & 87,533 & 281,549 & 18,504 & 11,286 & 5040 & 75 & 46,305 & 18.1 & 40.3 & & 152 \\
\hline AM-05-14 & 7701 & 9882 & 97,359 & 260,694 & 18,977 & 9643 & 5112 & 81 & 52,675 & 17.1 & 37.6 & 35.0 & 166 \\
\hline AM-05-15 & 5312 & 8634 & 103,611 & 271,259 & 27,093 & 3186 & 5418 & 93 & 51,870 & 16.3 & 38.6 & 42 & 175 \\
\hline AM-05-16 & 5379 & 8700 & 103,643 & 264,651 & 26,736 & 4136 & 5178 & 94 & 54,985 & 16.2 & 39.5 & 29 & 185 \\
\hline AM-05-17 & 4956 & 8550 & 106,544 & 263,317 & 26,927 & 3279 & 5100 & 99 & 55,132 & 17.0 & 42.0 & & 165 \\
\hline AM-05-18 & 5090 & 9012 & 110,435 & 252,910 & 27,6 & 44 & 4962 & 105 & & 17.3 & & & 147 \\
\hline AM-05-19 & 5194 & 9240 & 111,822 & 245,341 & & 53 & 4746 & 97 & & 16.7 & & & 163 \\
\hline AM-05-20 & 4971 & 2544 & 35,756 & 395,8 & 13,5 & 17 & 2784 & 29 & 21, & 10.9 & 20 & & 49 \\
\hline AM-0 & 4993 & 8724 & 105,427 & 260 & 27,3 & 33 & 5394 & 93 & & 17.9 & 4 & & 202 \\
\hline-22 & 4912 & 8376 & 727 & 264 & & & 5106 & 98 & & 17.5 & & & 160 \\
\hline-23 & 4771 & 8688 & 109,403 & 253,871 & 27,6 & & 5124 & 93 & & 16.9 & 40 & & 150 \\
\hline AM-05-24 & 5105 & 6528 & 73,191 & 321,001 & & & 4818 & 66 & & 13.6 & 29.6 & & 87 \\
\hline AM-05-26 & 8532 & 8454 & 81,884 & 293,813 & 18,703 & 8136 & 4878 & 68 & 42,119 & 16.1 & 31.9 & 26 & 129 \\
\hline AM-05-27 & 8577 & 8352 & 79,835 & 297,626 & 18,355 & 8143 & 4770 & 65 & 41,9 & 15.6 & 31.0 & 32 & 144 \\
\hline AM-05-28 & 8443 & 8646 & 81,768 & 299,647 & 18,861 & 8171 & 5004 & 68 & 42,5 & 16.3 & 31.0 & 26 & 129 \\
\hline AM-05-29 & 7976 & 9120 & 90,731 & 277,079 & 19,724 & 7407 & 5202 & 77 & 45,920 & 16.2 & 36 & 32 & 178 \\
\hline AM-05-30 & 6715 & 9450 & 100,424 & 253,559 & 20,463 & 729 & 5184 & 92 & 52,5 & 15.8 & & & 219 \\
\hline AM-05-31 & 8896 & 9144 & 83,425 & 296,60 & 19,1 & & 5208 & 77 & 43 , & 16.2 & & & 120 \\
\hline AM-05-32 & & 9348 & & & & & & 81 & & 15.8 & & & 125 \\
\hline & & & & & & & & & & 16.4 & & & 181 \\
\hline & 732 & 827 & & & & & 595 & 65 & & 15.7 & & & 101 \\
\hline-35 & 835 & 6876 & & & & & 4146 & 48 & & 12.4 & & & 92 \\
\hline-36 & 8577 & 6936 & 67,961 & 325,313 & 17,060 & & 4062 & 49 & $34, ?$ & 13.2 & 24 & & 93 \\
\hline AM-05-37 & 8332 & 7764 & 75,907 & 312,522 & 18,206 & & 4590 & 51 & & 13.0 & & 21 & 102 \\
\hline AM-05-38 & 7301 & 9330 & 95,199 & 275,333 & 20,745 & 760 & 5238 & 70 & & 15.0 & 36.2 & 39 & 176 \\
\hline AM-05-39 & 8406 & 8862 & 82,911 & 293,547 & 19,284 & & 5238 & 60 & & 15.3 & 28 & 26 & 115 \\
\hline AM-05-40 & 8970 & 7926 & 72,784 & 315,887 & 17,923 & 822 & 4686 & 51 & 37,072 & 13.4 & 24 & 22 & 96 \\
\hline AM-05-41 & 7204 & 9324 & 95,765 & 262,379 & 20,413 & & 5130 & 76 & 51,849 & 15.7 & 36 & 46 & 192 \\
\hline ËM-05-43 & 7679 & 9054 & 90,429 & 280,789 & 20,197 & & 5310 & 72 & & 15.6 & 33 & 30 & 136 \\
\hline AM-05-44 & & 5718 & & 359,973 & & & 14,334 & 114 & & 12.3 & & & 81 \\
\hline & & & & & & & & 1 & & 5.1 & & & 33 \\
\hline & & & & & & & & 2 & & 5.8 & & & 32 \\
\hline$-06-02$ & 8777 & 4392 & 36,842 & 391,216 & 11,849 & 78 & 2964 & 36 & & 8.6 & 17 & 6. & 50 \\
\hline AM-06-03 & 7486 & 3168 & 31,426 & 401,534 & 11,401 & 5807 & 1848 & 24 & 16,6 & 7.3 & & 5. & 35 \\
\hline AM-06-04 & 6180 & 2982 & 25,481 & 405,258 & 8895 & 5200 & 2970 & 26 & 17,528 & 6.3 & 14.7 & 4.5 & 36 \\
\hline AM-06-05 & 11,040 & 6030 & 47,017 & 361,844 & 13,492 & 10,686 & 5466 & 59 & 32,963 & 11.8 & 22.3 & 8.0 & 72 \\
\hline AM-06-06 & 7983 & 3780 & 32,538 & 399,317 & 10,829 & & 2952 & 30 & 18,375 & 6.8 & 14.6 & 4.3 & 41 \\
\hline AM-06-07 & 10,714 & 7866 & 70,306 & 319,079 & 17,359 & 10,000 & 3942 & 55 & 34,419 & 13.1 & 26.7 & 21.5 & 102 \\
\hline AM-06-08 & 8599 & 10,392 & 91,668 & 273,644 & 19,774 & 9536 & 5010 & 74 & 46,655 & 17.1 & 35.1 & 35.3 & 164 \\
\hline AM-06-09 & 7783 & 10,716 & 98,042 & 264,077 & 20,579 & 8650 & 5028 & 75 & 49,693 & 16.3 & 33 & 34 & 140 \\
\hline AM-06-10 & 8925 & & 86,019 & 280,224 & 19,027 & 10,1 & 4824 & 66 & 44,6 & 15.7 & 31 & 28.6 & 129 \\
\hline & & & & & & & & 72 & & 16.4 & & & 134 \\
\hline & & & & & & & & 69 & & 16.1 & & & 130 \\
\hline AM-06-13 & & & & & & & & 100 & & 16.1 & & & 138 \\
\hline AM-06-14 & 7301 & 10,770 & 100,535 & 260,358 & 20,778 & 9050 & 5064 & 78 & 50,092 & 16.3 & 34.0 & 31.6 & 142 \\
\hline AM-06-15 & 10,402 & 8790 & 79,539 & 298,769 & 17,857 & 10,650 & 4416 & 57 & 39,452 & 14.9 & 27.7 & 21.5 & 112 \\
\hline AM-06-16 & 8080 & 9714 & 90,349 & 275,627 & 18,720 & 10,079 & 4962 & 68 & 47,810 & 15.3 & 30.6 & 26.2 & 145 \\
\hline AM-06-17 & 6915 & 10,188 & 98,074 & 262,999 & 19,417 & 8543 & 4896 & 75 & 51,940 & 16.7 & 34.6 & 33.1 & 177 \\
\hline AM-06-18 & 6729 & 10,158 & 99,450 & 260,993 & 19,483 & 9721 & 4848 & 76 & 53,627 & 16.6 & 33.9 & 31.8 & 151 \\
\hline
\end{tabular}

${ }^{\mathrm{a}} \mathrm{BDL}$, below detection limit. 
the ratio $\mathrm{X}_{w} / \mathrm{X}_{p}$, which is a way to quantify the solubility of an element. $\mathrm{X}_{w}$ is the representative value for the quantity of an element present as dissolved species in one liter of Solimões river water. $\mathrm{X}_{p}$ is the representative value for the quantity of the same element transported in the particulate phase in one liter of Solimões river water. To calculate $\mathrm{X}_{w}$ and $\mathrm{X}_{p}$, average of dissolved concentrations [Bouchez, 2009; Bouchez et al., 2010b] and suspended sediment concentrations and chemical composition (Tables 1 and 2) were calculated over all available Solimões samples. The more an alkali element is soluble (the higher $\mathrm{X}_{w} / \mathrm{X}_{p}$ is), the more enriched in coarse sediments it is. Since Goldschmidt [1937], A-AE are broadly considered as soluble elements because they easily form monoatomic cations in aqueous solution. However, the affinity between alkali elements and soil phyllosilicates increases with ionic radius, resulting in a so-called lyotropic series [Jenny, 1932]. Altogether, this demonstrates that there is a tight relationship between the chemical properties of these alkali elements (e.g., ionic radius), their solubility and their behavior with respect to hydrodynamic sorting.

[40] The fan-shaped diagram of Figure 7 is the graphic representation of the gradual depletion/ enrichment of the finest fraction compared to the coarsest from $\mathrm{Na}$ (and $\mathrm{Ca}$ ) to $\mathrm{Cs}$. These various depletion/enrichment patterns offer a new approach for considering the geochemical mobility of A and $\mathrm{AE}$ elements through the whole spectrum of grain size produced by weathering processes.

\subsubsection{Toward a New Geochemical Classification of Elements During Weathering and Erosion}

[41] At this stage, based on the fan-shaped diagram (Figure 7), a classification of elements during erosion and transport in the Amazon Basin can be proposed as follows.

[42] 1. Th, REEs, Cr, Cu, Ga, Zn, Al and Fe concentration variations in the river with channel depth are simply due to the dilution of an Al-rich component by quartz. Some particular enrichment of Th and REEs can be observed in bed sediment samples due to concentration of heavy minerals. As these elements are all insoluble elements, their ratios are fairly constant over depth profiles and likely reflect the corresponding ratios of the continental crust eroded by the river. We propose to call them insoluble and poorly sorted elements.
[43] 2. Zr, Hf, Ti, Nb, Ta, Ge, and Co are not only diluted by quartz. Their variability with depth also stems from the occurrence of heavy minerals in the coarse sediments. Like those of the previous group, these elements are insoluble elements. They are insensitive to chemical weathering but are highly influenced by sorting in the river system. They are strongly fractionated by erosion processes, a feature that was already noticed and used for the $\mathrm{Lu} / \mathrm{Hf}$ isotopic system [Patchett et al., 1984]. We propose to call this group the insoluble and wellsorted elements.

[44] 3. Alkali and alkali-earth elements (A-AE) are depleted in the fine samples compared to the coarse samples, except for Cs, and a remarkable gradual "enrichment/depletion" factor from $\mathrm{Na}$ and $\mathrm{Ca}$ to $\mathrm{Cs}$ is depicted in the Solimões River basin. The patterns of these elements in the fan-shaped diagram (Figure 7) show that phases other than quartz and clays are necessary to explain their compositional gradient in the river column. These elements are not best characterized by their solubility, since they display various contributions of dissolved load to total transport, but rather by their mobility during weathering reactions that enrich fine fractions in heavy alkali elements and coarse fractions in light alkali elements.

[45] Finally, the observations and conclusions reported here for the Solimões also apply to the Madeira river system. It can be seen from Figure 7 that a steeper gradient for $\mathrm{Zr}$ but flatter patterns for A-AE characterize the Madeira River. Future studies will be necessary to tell whether these conclusions deduced from the Amazon river system apply to other large river systems. The differences between the two subbasins are examined below in more detail (section 4.3).

\subsection{Identification of the Mineralogical End-Members Explaining A-AE Patterns}

[46] The above discussion shows that the relationships between element concentrations (or ratios) and grain size can be interpreted in terms of mineralogical mixing. Since quartz dilution is not the only process explaining $\mathrm{A}-\mathrm{AE}$ abundances in depth profiles of suspended sediments (Figure 7), additional mineralogical phases are necessary to explain the observed patterns.

[47] XRD investigation revealed a large variety of minerals. Qualitative inspection shows that quartz is present in all samples and albite in almost all samples. Zircons, rutile and anatase were detected 


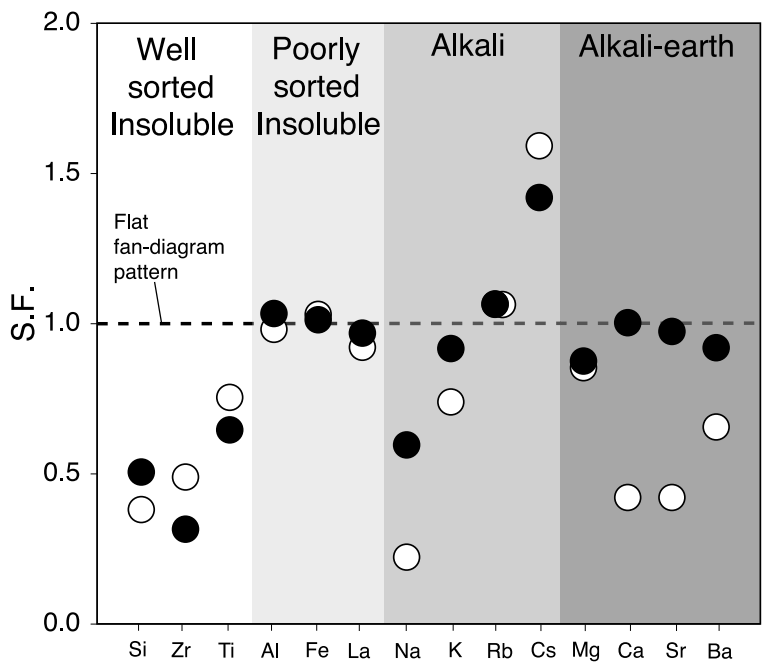

Figure 9. S.F. (sorting factor between fine and coarse particles) for the chemical elements, ranked following the classification established in section 4.1. White symbols represent Solimões River data, and black symbols represent Madeira River data. S.F. was assumed to be 1 for $\mathrm{Ca}$ in the Madeira River.

in bed sediment samples, consistently with the findings of Vital et al. [1999] and Vital and Stattegger [2000]. In all samples, kaolinite, illite, chlorite were found; in the $<2 \mu \mathrm{m}$ fraction, vermiculite and smectite were additionally identified, consistently with the findings of Gibbs [1967], Vital et al. [1999], and Guyot et al. [2007]. No carbonates or micas were detected. The identified minerals explain qualitatively the two main endmembers of the observed grain size- $\mathrm{Al} / \mathrm{Si}$ correlation. As demonstrated above, coarse, low-Al/Si sediments found near the bottom of the channel are quartz rich, but probably also albite rich. The aluminous phase enriched in fine suspended sediments is better explained by a phyllosilicate minerals assemblage, these minerals being usually small, tabular and relatively light, and thus expected to be preferentially transported at the surface of the water column. The correlation in Figure 4 thus reflects the finer nature of secondary Al-rich minerals (clays) [Meunier, 2006] compared to Si-rich primary minerals (such as quartz, feldspars, etc.).

[48] The ${ }^{87} \mathrm{Sr} /{ }^{86} \mathrm{Sr}$ ratio in river sediment reflect that of bedrock minerals or of secondary minerals resulting from their chemical alteration in soils. The lowest isotopic ratios found in the coarse sample are compatible with the presence of feldspars, which are relatively dense minerals, and are thus likely to be enriched near the bottom of the channel. The increase of ${ }^{87} \mathrm{Sr} /{ }^{86} \mathrm{Sr}$ with increasing $\mathrm{Al} / \mathrm{Si}$ in the Solimões and Amazon rivers is consistent with the occurrence of phyllosilicates in the finest samples because these minerals have relatively high $\mathrm{Rb} / \mathrm{Sr}$ ratios and with time acquire radiogenic compositions. These phyllosilicates are likely to be illite, kaolinite, chlorite, smectite and vermiculite as indicated by XRD analyses (since micas have not been detected). These phyllosilicates do not contain high amounts of $\mathrm{Na}$ and $\mathrm{Ca}$, but may contain significant amounts of $\mathrm{K}$ (in illite), $\mathrm{Mg}$ (in smectites), $\mathrm{Rb}$ and $\mathrm{Cs}$ (in illite and interfoliar spaces of smectites) [e.g., Poinssot et al., 1999]. From $\mathrm{Na}$ to $\mathrm{Cs}$, the increase in ionic radius tends to facilitate the incorporation in clay interlayers [e.g., Jenny, 1932; Sawhney, 1972], which is in turn likely due to the size of the hydration sphere of their aqueous species. This mechanism explains the relationship between alkali elements enrichment in the fine sediments of the Amazon River and their ionic radius, as well as their decreasing solubility with increasing ionic radius (Figure 8). Despite being not detectable by XRD, small amounts of micas might also be present in the fine sediments and contribute to the A-AE patterns.

[49] As a conclusion, A-AE patterns are mainly the results of a mixing of coarse feldspars (enriched in low-Al/Si samples) and an assemblage of fine clay particles (enriched in high- $\mathrm{Al} / \mathrm{Si}$ samples). The enrichment of $\mathrm{A}-\mathrm{AE}$ in the coarse fraction could also partly be attributed to the occurrence of heavy minerals and of lithic fragments [Franzinelli and Potter, 1983; Johnsson and Meade, 1990], provided that these lithic fragments are inherited from regions of low $\mathrm{Sr}$ isotopic ratios (for example, from the volcanic areas of the Andes). It should also be emphasized, for a more complete picture, that oxy-hydroxides and organic matter are likely to be enriched in the finest, near surface suspended load samples.

\subsection{Comparison Between the Solimões and the Madeira: The Weathering-Sorting- Lithology Triptych}

[50] Several differences can be observed between the Solimões and Madeira rivers in terms of element concentrations, $\mathrm{Al} / \mathrm{Si}$ range and chemical ratios. Here we attempt to explain these differences and to distinguish the effects of weathering processes, sorting processes and composition of the continental crust from which river sediments are derived.

[51] The differences between the two basins in terms of sorting of chemical elements can be explored 
Table 3. Isotopic Ratios of $\mathrm{Sr}$ and $\mathrm{Nd}^{\mathrm{a}}$

\begin{tabular}{lccccc}
\hline Sample & ${ }^{87} \mathrm{Sr} /{ }^{86} \mathrm{Sr}$ & ${ }^{143} \mathrm{Nd} /{ }^{144} \mathrm{Nd}$ & Sample & ${ }^{87} \mathrm{Sr} /{ }^{86} \mathrm{Sr}$ & ${ }^{143} \mathrm{Nd} /{ }^{144} \mathrm{Nd}$ \\
\hline AM-05-15 & 0.733377 & N.D. & AM-06-36 & 0.732585 & 0.512054 \\
AM-05-17 & 0.733729 & N.D. & AM-06-38 & 0.733749 & 0.512018 \\
AM-05-18 & 0.732780 & 0.512198 & AM-06-39 & 0.732746 & 0.512027 \\
AM-05-19 & 0.732524 & 0.512098 & AM-06-40 & N.D. & 0.512046 \\
AM-05-20 & N.D. & 0.512135 & AM-06-43 & 0.732881 & 0.512083 \\
AM-06-05 & 0.709477 & 0.512534 & AM-06-44 & 0.721334 & 0.512078 \\
AM-06-07 & 0.713024 & 0.512206 & AM-06-63 & 0.720738 & 0.512127 \\
AM-06-10 & 0.713024 & 0.512193 & AM-06-64 & 0.722395 & 0.512141 \\
AM-06-11 & 0.714477 & 0.512210 & AM-06-65 & N.D. & 0.512229 \\
AM-06-13 & 0.714749 & 0.512196 & AM-06-66 & 0.716047 & 0.512333 \\
AM-06-14 & 0.715431 & 0.512101 & & & \\
\hline
\end{tabular}

${ }^{\mathrm{a}}$ Relative uncertainties are $10 \mathrm{ppm}(2 \sigma)$.

using the fan-shaped diagram (section 4.1) and the S.F. ratio as defined in section 4.1.3. In Figure 9, in which the S.F. ratio is shown for the two river systems, chemical elements are grouped by families as defined in section 4.1. For the Solimões, S.F. ranges from $0.22(\mathrm{Na})$ to $1.59(\mathrm{Cs})$, whereas for the Madeira, it ranges from $0.31(\mathrm{Zr})$ to $1.42(\mathrm{Cs})$, and only from $0.60(\mathrm{Na})$ to $1.42(\mathrm{Cs})$ for alkali elements. Nevertheless, the progressive depletion/enrichment pattern as a function of ionic radius of alkali elements (section 4.1.3) is also observed in the Madeira. For the Madeira, alkali-earth elements are close to the horizontal line S.F. $=1$, whereas significant fractionations were observed for the Solimões for alkali-earth elements in section 4.1.3. Finally, for both rivers, sorted insoluble elements have comparable S.F. values. Therefore, with the noticeable exception of $\mathrm{Zr}$ and $\mathrm{Ti}$, hydrodynamic fractionation throughout depth is weaker in the Madeira than in the Solimões. In other words, Madeira sediments are more homogenous than those of the Solimões. This feature is also visible (1) in the grain size distributions, for which the Madeira River display more homogenous patterns than the Solimões River (section 3.1), and (2) on the range of ${ }^{87} \mathrm{Sr} /{ }^{86} \mathrm{Sr}$ ratios (Table 3 and Figure 6); the relative variability of $\mathrm{Sr}$ isotopic ratios is $3.4 \%$ for the Solimões suspended load, and only $1.7 \%$ for the Madeira suspended load.

[52] The flatter patterns of $\mathrm{Na}, \mathrm{K}, \mathrm{Ca}$, and $\mathrm{Sr}$ obtained for the Madeira in the fan-shaped diagram (Figures 7 and 9) are explained by the depletion of primary minerals containing these elements in the low-Al/Si sediments compared to the Solimões. For example, an absence of plagioclase would result in the depletion of $\mathrm{Na}$ in the coarse fraction. The potentially very low content of feldspars in the coarsest fraction of the Madeira River sediments compared to the Solimões River sediments could be attributed to (1) hydrodynamic sorting, i.e., preferential deposition of feldspars between the sediment source region and the sampling site (physical effect), (2) weathering in Andean soils or in the floodplain (chemical effect), and (3) crustal composition (source effect).

[53] Because the two river basins do not drastically differ in terms of geomorphic features and both have the ability to transport zircons and other heavy minerals in the coarse fractions (as clearly shown by Figure 7), both river systems likely have similar ability to transport feldspars from the source areas to the outlet. Furthermore, the flux of dissolved $\mathrm{Na}$ exported out of the Solimões drainage basin, once corrected from rain input, is about $250-350 \mathrm{~kg} / \mathrm{s}$, i.e., more than twice the flux of dissolved $\mathrm{Na}$ at the outlet of the Madeira River basin, which is $30-100 \mathrm{~kg} / \mathrm{s}$, depending on the water stage. These numbers have been calculated using water discharge determined by ADCP on the day of sampling and the concentrations of $\mathrm{Cl}$ and $\mathrm{Na}$ measured in the dissolved phase [Bouchez et al., 2010b]. Because albite is the main mineral that provides dissolved $\mathrm{Na}$ during chemical weathering reactions, these fluxes suggest that albite weathering is more important in the Solimões basin than it is in the Madeira basin. Moreover, climate, surface area and geomorphic conditions are not significantly different between the Solimões and Madeira river systems. This analysis suggests that the very low content of albite in the suspended sediments of the Madeira River is not due to albite dissolution by present chemical weathering. The amount of feldspars in the suspended sediments of the Solimões and Madeira rivers is thus most probably related to their occurrence in the bedrock. This conclusion is consistent with the geology of the two basins: the Madeira River drains mostly sedimentary rocks while an additional magmatic subduction-related 
component is present in the Solimões River basin. This is confirmed by geochemical studies [Basu et al., 1990; Allègre et al., 1996; Viers et al., 2008] that all detected, based on $\mathrm{Nd}$ and $\mathrm{Sr}$ isotopic ratios, a relatively recent magmatic component in the Solimões River sediments, and not in the Madeira River sediments.

[54] The differences in the fan-shaped diagram patterns between the Solimões and Madeira rivers (Figure 7) are thus related to the nature of the continental crust submitted to chemical weathering. "Flat" patterns of A-AE characterize highly evolved sedimentary crustal material, i.e., a mixing between coarse quartz and heavy minerals on one hand, and fine phyllosilicate assemblages on the other hand. In the Solimões, a magmatic component constitutes a source of $\mathrm{Na}-$ and $\mathrm{Ca}$-containing primary minerals and lithic fragments, that mix with quartz, heavy minerals and clays, giving rise to a higher degree of chemical variability with grain size. This is also shown by Sr isotopes (Figure 6): the Solimões River system mixes nonradiogenic minerals, enriched in the coarse suspended sediments and likely deriving from magmatic areas of the Andes; with more radiogenic minerals such as micas or sedimentary clays, enriched in the finest samples, and similar to those found in the Madeira suspended load. Sorting in Solimões-like river systems induces an isotopic fractionation leading to more radiogenic phases in the fine-grained fraction for $\mathrm{Sr}$ and less radiogenic phases for $\mathrm{Nd}$. This fractionation is possible because of the occurrence of feldspars or lithic fragments in the suspended sediments.

[55] The present-day weathering processes do not permit the weathering of all primary minerals that are evacuated out of the Solimões river system. Conversely, the sedimentary rocks that constitute most of the Madeira River drainage basin were affected over geological times by successive reworking and weathering episodes, which have led to progressive loss of $\mathrm{Ca}$ and $\mathrm{Na}$ elements and to the flat patterns observed in Figure 7. In other words, sedimentary cannibalism [Veizer and Jansen, 1979] explains the distribution of $\mathrm{Na}$ and $\mathrm{Ca}$ with grain size in the suspended sediments of the Madeira River.

[56] We conclude from the above discussion that the differences between the Solimões and Madeira rivers in terms of effects of hydrodynamic sorting on chemical elements distribution are not only influenced by present-day weathering and sorting regimes, but also largely by bedrock characteristics. The persistence of unweathered minerals or lithic fragments in the Solimões River sediments shows that the weathering conditions (climate, soil development and residence time) in the magmatic provinces from which they derive are not active enough to entirely transform them into clay minerals. We speculate that more drastic weathering regimes (higher precipitation and temperature, deeper soils with longer residence time) could have led to the absence of feldspars or lithic fragments in the river sediments of the Solimões and less differences between the chemical depth profiles of Solimões and Madeira river sediments. Altogether, a combination of bedrock composition, weathering intensity in soils and hydrodynamic processes during transport determines the distribution of elements along the grain size range of river sediments.

\subsection{Sr Isotopes as a Tracer of a "Stratification of Sediment Source" in the Amazon River}

[57] The very distinct $\mathrm{Sr}$ isotopic signatures of the Solimões and the Madeira rivers allow us to constrain their relative contribution in the Amazon River, and to trace the particles in the mixing process. As shown in Figure 6, the Amazon River at Óbidos displays very different ${ }^{87} \mathrm{Sr} /{ }^{86} \mathrm{Sr}$ ratios as a function of $\mathrm{Al} / \mathrm{Si}$. The Al-rich samples have a $\mathrm{Sr}$ isotopic composition close to the one of the Madeira, whereas the Si-rich samples have less radiogenic ${ }^{87} \mathrm{Sr} /{ }^{86} \mathrm{Sr}$, resembling the Solimões samples. The contribution of the Madeira River to the Amazon sediments thus varies with grain size, the Madeira sediments being enriched near the surface of the channel of the Amazon at Óbidos. This is confirmed by $\mathrm{Nd}$ isotopes: at Óbidos, the highest $\epsilon_{N d}$ are obtained for low- $\mathrm{Al} / \mathrm{Si}$ samples collected at depth (higher than -8.2), similarly to the Solimões sediment samples (mostly around -8.2). The lowest $\epsilon_{N d}$ are measured in channel surface sediments (close to -10$)$, similarly to what is observed in Madeira sediments. Using $\mathrm{Sr}$ isotopes in the mixing equation

$$
\begin{aligned}
\left({ }^{87 \mathrm{Sr}}\right)_{\text {Obidos }}= & \mathrm{X}_{\text {Solimoes }} \cdot\left(\frac{{ }^{87} \mathrm{Sr}}{{ }^{86} \mathrm{Sr}}\right)_{\text {Solimoes }} \\
& +\left(1-\mathrm{X}_{\text {Solimoes }}\right) \cdot\left(\frac{{ }^{87} \mathrm{Sr}}{{ }^{86} \mathrm{Sr}}\right)_{\text {Madeira }}
\end{aligned}
$$

with $\mathrm{X}_{\text {Solimoes }}=\frac{[\mathrm{Sr}]_{\text {Solimoes }}}{[\mathrm{Sr}]_{\text {Obidos }}} \cdot \frac{\mathrm{M}_{\text {Solimoes }}}{\mathrm{M}_{\text {Obidos }}}$, with $\frac{\mathrm{M}_{\text {Solimoes }}}{\mathrm{M}_{\text {Obidos }}}$ being the weight proportion of Solimões-supplied sediments in the Amazon sediments at Óbidos. Taking a mean ${ }^{87} \mathrm{Sr} /{ }^{86} \mathrm{Sr}$ of 0.713 for the Solimões River sediments and a ${ }^{87} \mathrm{Sr} /{ }^{86} \mathrm{Sr}$ of 0.735 for Madeira sediments, a mixing equation yields ca. $90 \%, 70 \%$ 
and $60 \%$ of Solimões sediments in the Amazon sediments, respectively, for bed sediment, suspended load at $-45 \mathrm{~m}$ and $-20 \mathrm{~m}$. Thus, in the Amazon River, the Madeira solid material is preferentially transported near the channel surface, whereas the Solimões River is preferentially transported near the channel bottom. This conclusion is consistent with the smaller grain size of Madeira sediments compared to Solimões sediments: once the sediments of both tributaries are transported one single channel, i.e., the Amazon, the relatively coarser sediments of the Solimões are hydrodynamically enriched near the bottom of the channel. We emphasize that this feature is probably not transient: the described mechanism of hydrodynamic sorting is also valid for steady state transport. To our knowledge, this is the first time that such a "stratification" of sediment provenance is reported in a large river system.

\section{Conclusion}

[58] From depth profiles of river water sampling, made at two distinct water stages and in five locations of the largest river basin on Earth, the Amazon River appears to act as a "sorting machine" of erosion products of the Andes. Important gradients in chemical and isotopic compositions are observed at all locations with depth, best characterized by the $\mathrm{Al} / \mathrm{Si}$ ratio chemical index. A major result of this study is that a basin-wide inverse relationship is observed between grain size and $\mathrm{Al} / \mathrm{Si}$ ratio, Al-rich, clay-rich samples being the finest, and Si-rich, quartz-rich samples being the coarsest. The quartz enrichment from channel surface to bottom and then to bed sediment, induced by hydrodynamic sorting, explains a large part of the variability in chemical composition of Amazon riverine sediments. A double-normalization (fan-shaped) diagram is proposed in this paper to correct for dilution effects of clay minerals by quartz and shows that additional processes of mineralogical sorting within the water column are needed to explain the distribution of chemical elements throughout the $\mathrm{Al} / \mathrm{Si}$ spectrum.

[59] Another significant result of this study is the enrichment of the finest fraction of river suspended sediments (in terms of absolute concentrations) in a large number of major ( $\mathrm{Al}, \mathrm{Fe}, \mathrm{K}, \mathrm{Mg}$ ) and trace (Th, REEs, Co, Zn, Rb, Cs) elements relatively to the coarse fraction. Isotopically, $\mathrm{Sr}$ and $\mathrm{Nd}$ isotope ratios are significantly more radiogenic in the finest suspended sediments, at least in the Solimões River. Therefore, sorting of river products results in significant chemical and isotopic fractionations, implying that (1) the composition of river suspended sediments in large river systems can only be known precisely if it is integrated along depth profiles and (2) fine sedimentary rocks do not necessarily record the concentrations and isotopic ratios of the bedrock from which they derive; $\mathrm{Sr}$ and $\mathrm{Nd}$ isotopic ratios of fine sediments may not be a reliable record of the crustal bedrocks, a finding with important implications regarding studies of continental crust evolution. Interestingly, $\mathrm{Sr}$ isotopes show that the Amazon River profiles result from a mixing between these two tributaries with the suspended sediments of the top and the bottom of the depth profiles preferentially derived from the Madeira and Solimões river sediments, respectively.

[60] We established in this paper a classification of elements during erosion and transport for the Amazon Basin. Three main groups can be distinguished. The first group is composed of insoluble and poorly sorted elements $\mathrm{Th}, \mathrm{REEs}, \mathrm{Cr}, \mathrm{Cu}, \mathrm{Ga}$, $\mathrm{Zn}, \mathrm{Al}$ and $\mathrm{Fe}$, in which concentration variations in the river with channel depth are simply due to the dilution of an Al-rich component (most likely a phyllosilicate assemblage) by quartz. The second group is composed of insoluble and well-sorted elements $\mathrm{Zr}, \mathrm{Hf}, \mathrm{Ti}, \mathrm{Nb}, \mathrm{Ta}, \mathrm{Ge}$ and $\mathrm{Co}$, in which concentration variabilities with depth are also due to the presence of heavy minerals in the coarse sediments. The third group is composed of alkali and alkali-earth elements (A-AE); they are soluble elements and are partitioned between dissolved and suspended load, except Cs. They are not only diluted by quartz, but their variability also reflects the mixing of a phyllosilicate component, preferentially transported at the river surface and primary minerals (i.e., feldspars and lithic fragments) in the coarsest fraction. A remarkable chemical gradient of the "sorting factor" of alkali elements (from $\mathrm{Na}$ to $\mathrm{Cs}$ ) is observed in the Solimões River basin, related to their mobility during weathering, and to their gradual affinity with secondary phyllosilicates.

[61] The Madeira River profiles appear less variable than those of the Solimões in terms of chemistry and grain size distribution. Arguments based on the alkali elements suggest that the low chemical and isotopic variability of the Madeira River profiles is controlled by crustal rock composition rather than by present-day weathering conditions. Our results suggest that recycled crust leads to homogenized profiles, while magmatic crust will favor the sorting of grains, provided that weathering conditions are not too drastic.

[62] The composition of river particles results from the interplay of crustal bedrock type (recycled 
versus primary), weathering (and the controlling factors, i.e., climate, residence time, etc.) and sorting processes (hence hydrodynamic and geomorphologic properties). These three parameters can define what we call an erosion regime, encompassing present-day weathering conditions, bedrock type and fluvial transport features. Any use of past river sediments to infer paleoenvironmental conditions will have to take into account these three controlling parameters and their interplay. The investigation of other river systems is clearly necessary to infer a more global picture on the links between sediment composition and erosion systems.

\section{Acknowledgments}

[63] This work was funded by the "Reliefs de la Terre" INSUCNRS program. The field campaigns, supported by the French Institute for Development (IRD), were realized in the frame of the HyBAm (Hydrology and Geochemistry of the Amazonian Basin, http:/www.mpl.ird/hybam/), in which the cooperation agreement with the Brazilian Research Centre (CNPq) is 492685/2004-5. We sincerely acknowledge the Brazilian Institutions and Universities (ANA, UnB, UFF, CPRM), which collaborated on this project. We particularly thank P. MoreiraTurcq for the organization and all the staff of the $\mathrm{C}^{\text {te }}$ Cuadros ship for their help during the field work. B. Lartiges, N. Findling, J.-L. Birck, and F. Capmas are greatly acknowledged for their analytical help. B. Velde and N. Hovius are thanked for helpful discussions. E. Garzanti and an anonymous reviewer greatly helped us to improve the paper. This is IPGP contribution 3122.

\section{References}

Albarède, F., and K. Semhi (1995), Patterns of elemental transport in the bedload of the Meurthe River (NE France), Chem. Geol., 122, 129-145.

Allègre, C. J., B. Dupré, P. Négrel, and J. Gaillardet (1996), $\mathrm{Sr}-\mathrm{Nd}-\mathrm{Pb}$ isotope systematics in Amazon and Congo river systems: Constraints about erosion processes, Chem. Geol., 131, 93-112.

Basu, A. R., M. Sharma, and P. G. DeCelles (1990), Nd, Sr-isotopic provenance and trace elements geochemistry of Amazonian foreland basin fluvial sands, Bolivia and Peru: Implications for ensialic Andean orogeny, Earth Planet. Sci. Lett., 100, 1-17.

Birck, J. L. (1986), Precision K-Rb-Sr isotopic analysis: Application to Rb-Sr chronology, Chem. Geol., 56, 73-83.

Bouchez, J. (2009), Dynamique sédimentaire et cinétiques d'altération dans les grands fleuves, Ph.D. thesis, Univ. Paris Diderot, Paris.

Bouchez, J., F. Métivier, M. Lupker, L. Maurice, M. A. Perez, and C. France-Lanord (2010a), Prediction of depth-integrated fluxes of suspended sediment in the Amazon River: Particle aggregation as a complicating factor, Hydrol. Processes, 25, 778-794, doi:10.1002/hyp.7868.
Bouchez, J., E. Lajeunesse, J. Gaillardet, C. France-Lanord, P. Dutra-Maia, and L. Maurice (2010b), Turbulent mixing in the Amazon River: The isotopic memory of confluences, Earth Planet. Sci. Lett., 290, 37-43.

Canfield, D. E. (1997), The geochemistry of river particulates from the continental USA: Major elements, Geochim. Cosmochim. Acta, 61, 3349-3365.

Chen, J., J. Gaillardet, P. Louvat, and S. Huon (2009), Zn isotopes in the suspended load of the Seine River, France: Isotopic variations and source determination, Geochim. Cosmochim. Acta, 73, 4060-4076.

Cullers, R. L. (1995), The controls on the major- and traceelement evolution of shales, siltstones and sandstones of Ordovician to Tertiary age in the Wet Mountains region, Colorado, U.S.A, Chem. Geol., 123, 107-131.

Cullers, R. L., B. Bock, and C. Guidotti (1997), Elemental distribution and neodymium isotopic compositions of Silurian metasediments, western Maine, USA: Redistribution of the rare earth elements, Geochim. Cosmochim. Acta, 61, $1847-1861$.

Dosseto, A., B. Bourdon, J. Gaillardet, L. Maurice-Bourgoin, and C. J. Allègre (2006), Weathering and transport of sediments in the Bolivian Andes: Time constraints from uranium-series isotopes, Earth Planet. Sci. Lett., 248, 759-771.

Douglas, G. B., C. M. Gray, B. T. Hart, and R. Beckett (1995), A strontium isotopic investigation of the origin of suspended particulate matter (SPM) in the Murra-Darling River system, Australia, Geochim. Cosmochim. Acta, 59, 3799-3815.

Dunne, T., L. A. K. Mertes, R. H. Meade, J. E. Richey, and B. R. Forsberg (1998), Exchanges of sediment between the flood plain and channel of the Amazon River in Brazil, Geol. Soc. Am. Bull., 110(4), 450-467.

Dupré, B., J. Gaillardet, D. Rousseau, and C. J. Allègre (1996), Major and trace elements of river-borne material: The Congo Basin, Geochim. Cosmochim. Acta, 60, 1301-1321.

Elbaz-Poulichet, F., P. Seyler, L. Maurice-Bourgoin, J.-L. Guyot, and C. Dupuy (1999), Trace element geochemistry in the upper Amazon drainage basin (Bolivia), Chem. Geol., 157, 319-334.

Filizola, N., and J.-L. Guyot (2004), The use of Doppler technology for suspended sediment discharge determinations on the River Amazon at Óbidos, Hydrol. Sci. J., 49(1), $143-153$.

France-Lanord, C., and L. A. Derry (1997), Organic carbon burial forcing of the carbon cycle from Himalayan erosion, Nature, 390, 65-67.

Franzinelli, E., and P. E. Potter (1983), Petrology, chemistry, and texture of modern river sands, Amason River system, J. Geol., 91, 23-39.

Gaillardet, J., B. Dupré, C. J. Allègre, and P. Négrel (1997), Chemical and physical denudation in the Amazon River Basin, Chem. Geol., 142, 141-173.

Gaillardet, J., B. Dupré, and C. J. Allègre (1999), Geochemistry of large river suspended sediments: Silicate weathering or recycling tracer?, Geochim. Cosmochim. Acta, 63, 4037-4051.

Galy, V., C. France-Lanord, O. Beyssac, P. Faure, H. Kudrass, and F. Palhol (2007), Efficient carbon burial in the Bengal fan sustained by the Himalayan erosional system, Nature, 450, 407-410.

Galy, V., C. France-Lanord, and B. Lartiges (2008), Loading and fate of particulate organic carbon from the Himalaya to the Ganga-Brahmaputra delta, Geochim. Cosmochim. Acta, 72, 1767-1787. 
García, M. H. (2008), Sediment transport and morphodynamics, in Sedimentation Engineering: Processes, Measurements, Modeling and Practice, edited by M. H. García, pp. 21-145, Geol. Soc. of Civil Eng., Reston, Va.

Garzanti, E., S. Ando, C. France-Lanord, P. Censi, P. Vignola, V. Galy, and M. Lupker (2010a), Mineralogical and chemical variability of fluvial sediments. 2. Suspended-load silt (Ganga-Brahmaputra, Bangladesh), Earth Planet. Sci. Lett., 302, 107-120, doi:10.1016/j.epsl.2010.11.043.

Garzanti, E., S. Ando, C. France-Lanord, G. Vezzoli, P. Censi, V. Galy, and Y. Najman (2010b), Mineralogical and chemical variability of fluvial sediments. 1. Bedload sand (GangaBrahmaputra, Bangladesh), Earth Planet. Sci Lett., 299, 368-381, doi:10.1016/j.epsl.2010.09.217.

Gibbs, R. J. (1967), Amazon river system: Environmental factors that control its dissolved and suspended load, Science, 156, 1734-1737.

Goldschmidt, V. M. (1937), The principles of distribution of chemical elements in minerals and rocks, J. Chem. Soc., 655-673, doi:10.1039/JR9370000655.

Goldstein, S. J., R. K. O’Nions, and P. J. Hamilton (1984), A Sm-Nd isotopic study of atmospheric dusts and particulates from major river systems, Earth Planet. Sci. Lett., 70, 221-236

Goldstein, S. J., and S. B. Jacobsen (1988), Nd and Sr isotopic systematics of river water suspended material: Implications for crustal evolution, Earth Planet. Sci. Lett., 87, 249-265.

Granet, M., F. Chabaux, C. France-Lanord, P. Stille, and E. Pelt (2007), Time-scales of sedimentary transfer and weathering processes from U-series nuclides: Clues from the Himalayan rivers, Earth Planet. Sci. Lett., 261, 389-406.

Guyot, J.-L., J.-M. Jouanneau, L. Suares, G. R. Boaventura, N. Maillet, and C. Lagane (2007), Clay mineral composition of river sediments in the Amazon Basin, Catena, 71, 340-356.

Hedges, J. I., W. A. Clark, P. D. Quay, J. E. Richey, A. H. Devol, and U. de M. Santos (1986), Compositions and fluxes of particulate organic material in the Amazon River, Limnol. Oceanogr., 31, 717-738.

Hilton, R. G., A. Galy, and N. Hovius (2008), Riverine particulate organic carbon from an active mountain belt: Importance of landslides, Global Biogeochem. Cycles, 22, GB1017, doi:10.1029/2006GB002905.

Hofmann, A. W. (1988), Chemical differentiation the Earth: The relationship between mantle, continental crust and oceanic crust, Earth Planet. Sci. Lett., 90, 297-314, doi:10.1016/0012B21X(88)90132-X.

Jenny, H. (1932), Studies on the mechanism of ionic exchange in colloidal aluminum silicates, J. Phys. Chem., $36,2217-2258$.

Johnsson, M. J., and R. H. Meade (1990), Chemical weathering of fluvial sediments during alluvial storage: The Macuapanim Island point bar, Solimões River, Brazil, J. Sediment. Petrol., 60, 827-842.

Louvat, P., and C. J. Allègre (1997), Present denudation rates on the island of Réunion determined by river geochemistry: Basalt weathering and mass budget between chemical and mechanical erosions, Geochim. Cosmochim. Acta, 61, 3645-3669.

Martin, J. M., and M. Meybeck (1979), Elemental mass balance of material carried by world major rivers, Mar. Chem., 7, 173-206.

Maurice-Bourgoin, L., M.-P. Bonnet, J.-M. Martinez, P. Kosuth, G. Cochonneau, P. Moreira-Turcq, J.-L. Guyot, P. Vauchel,
N. Filizola, and P. Seyler (2007), Temporal dynamics of water and sediments exchanges between the Curuaí floodplain and the Amazon River, Brazil, J. Hydrol., 335, 140-156.

Meade, R. H., C. F. Nordin Jr., W. F. Curtis, F. M. Costa Rodrigues, C. M. Do Vale, and J. M. Edmond (1979), Sediments load in the Amazon River, Nature, 278, 161-163.

Meybeck, M., and A. Ragu (1996), River discharge to the oceans: An assessment of suspended solids, major ions and nutrients, environment information and assessment report, U. N. Environ. Programme, Nairobi, Africa.

Meunier, A. (2006), Why are clay mineral small?, Clay Miner., 41, 551-566.

Millot, R., C. J. Allègre, J. Gaillardet, and S. Roy (2004), Lead isotopic systematics of major river sediments: A new estimate of the $\mathrm{Pb}$ isotopic composition of the upper continental crust, Chem. Geol., 203, 75-90.

Molinier, M., J.-L. Guyot, E. De Oliveira, and V. Guimarães (1996), Les régimes hydrologiques de l'Amazone et de ses affluents, IAHS Publ., 238, 209-222.

Patchett, P. J., W. M. White, H. Feldmann, S. Kielinczuk, and A. W. Hofmann (1984), Hafnium/rare earth element fractionation in the sedimentary system and crustal recycling into the Earth's mantle, Earth Planet. Sci. Lett. 69, 365-378. doi:10.1016/0012-821X(84)90195-X.

Poinssot, C., B. Baeyens, and M. H. Bradbury (1999), Experimental and modelling studies of caesium sorption on illite, Geochim. Cosmochim. Acta, 63, 3217-3227.

Putzer, H. (1984), The geological evolution of the Amazon Basin and its mineral resources, in The Amazon: Limnology and Landscape Ecology of a Mighty Tropical River and its Basin, edited by H. Sioli, pp.15-46, Dordrecht, Netherlands.

Rouse, H. (1950), Engineering Hydraulics, Wiley, New York.

Sawhney, B. L. (1972), Selective adsorption and fixation of cations by clay minerals: A review, Clays Clay Miner., 20, 93-100.

Slingerland, R. (1977), The effect of entrainment on the hydraulic equivalence relationships of light and heavy minerals in sands, J. Sediment. Petrol., 33, 180-190.

Stallard, R. F., and J. M. Edmond (1983), Geochemistry of the Amazon 2. The influence of geology and weathering environment of the dissolved load, J. Geophys. Res., 88 , 9671-9688.

Veizer, J., and S. L. Jansen (1979), Basement and sedimentary recycling and continental evolution, J. Geol., 87, 341-370.

Viers, J., M. Roddaz, N. Filizola, J.-L. Guyot, F. Sondag, P. Brunet, C. Zouiten, C. Boucayrand, F. Martin, and G. R. Boaventura (2008), Seasonal and provenance controls on $\mathrm{Nd}-\mathrm{Sr}$ isotopic compositions of Amazon rivers suspended sediments and implications for $\mathrm{Nd}$ and $\mathrm{Sr}$ fluxes exported to the Atlantic Ocean, Earth Planet. Sci. Lett., 274, 511-523.

Viers, J., B. Dupré, and J. Gaillardet (2009), Chemical composition of suspended sediments in World Rivers: New insights from a new database, Sci. Total Environ., 407, 863-868.

Vigier, N., B. Bourdon, S. Turner, and C. J. Allégre (2001), Erosion timescales derived from U-decay series measurements in rivers, Earth Planet. Sci. Lett., 193, 549-563.

Vital, H., K. Stattegger, and C.-D. Garbe-Schönberg (1999), Composition and trace-element geochemistry of detrital clay and heavy-mineral suites of the lowermost Amazon River: A provenance study, J. Sediment. Res., 69, 563-575.

Vital, H., and K. Stattegger (2000), Major and trace elements of stream sediments from the lowermost Amazon River, Chem. Geol., 168, 151-168. 